\title{
唾液腺原発腺様囊胞癌についての病理学的検討
}

\author{
高 城 功 \\ 東京医科歯科大学歯学部口腔病理学教室 (主任 : 石川梧朗教授)
}

（昭和51年 2 月 2 日受付）

\section{Adenoid Cystic Carcinoma of the Salivary Glands}

\author{
Isao TAKAGI \\ Department of Oral Pathology, School of Dentistry, \\ Tokyo Medical and Dental University
}

(Director : Prof. Goro ISHIKAWA)

\begin{abstract}
要旨 : 大小唾液腺の腺様囊胞癌69例を検討した。年齢別では来院時40歳から70歳までが全体の約70\%で, 40 歳代が最も多い。性別では女性が男性の約 2 倍で, 従来の諸報告に比し女性に多い。発現部位別では口蓋 が最も多く全体の約 $1 / 3$ を占めていた。組織学的には，実質がいわゆる節状構造を示す典型像が主体をなす定 型例が34例と，他の型の唾液腺腫瘍との鑑別を要する種々の変異像が主体をなす非定型例が 35 例であった。

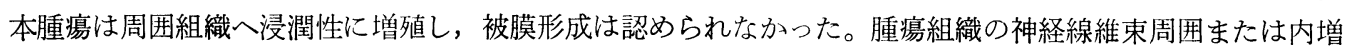
殖像は症例の約 $36 \%$ に認められた。顎骨への浸潤は上顎洞部, 口蓋, 臼後部に生じた例にみられ，組織学的 に非定型例に多かった。再発が組織学的に確認された症例は一次症例で 10 例 $(17 \%)$, 二次症例で 6 例 $(67 \%)$ であった。転移は頸部リンパ節転移が頸部廓清例 9 例中 6 例で確認され, 剖検例 4 例ではいずれも頸部リン 八節を含め広汎な遠隔転移が認められた。追跡調查では生存例が $52 \%$, 死亡確認例が $48 \%$ で，10年以上経過 後の生存例は 2 例, 死亡例は 4 例であった。組織学的に非定型例で, とくに充実性増殖像, 索状浸潤像, 管 状腺癌様像を示す例は予後が不良であった。
\end{abstract}

\section{I。緒言}

腺様囊胞癌は腺癌の 1 型であって, その特異な 組織形態よりかつては円柱腫なる名称で呼ばれ, 現在もなおての名称を用いる者もいる。本腫瘍は 腫瘍細胞の異型性あるいは核分裂像など覀性腫瘍 としての性格がそしく, 経過も長いために良性腫 瘍と誤認されたとともあった。しかし，本腫瘍の 発育は浸潤性で転移も生じ, 予後は悪く宿主を死 に至らしめることが明らかになり，その特異な組 織像と相俟って悪性腫瘍としての性格を明示する 腺様囊胞癌 adenoid cystic carcinoma の名称 が, 現在多くの人によって用いられている5,22,31, ${ }^{36,42,49,60)}$ 。本腫瘍は一般的には稀なものであり,
涙腺, 副鼻腔, 咽頭, 気管あるいは乳腺などにも 発生するが，崜液腺により多くみられ，とくに小 涶液腺腫瘍における頻度が高い $31,36,42) 。$ 本腫瘍は 臨床的にも, 病理学的にもいくつかの特徴的な所 見を有するが，組織像はときにかなり多彩で，他 の型の腺系腫瘍との鑑別がしばしば問題となる。

唾液腺腫瘍, 特に多形性腺腫に関しては従来よ り多数の研究が報告されてきたが, 腺様囊胞癌に ついての系統的検索は少なく，なかんずく，本邦 においてての種の報告はそしい。

著者は東京医科歯科大学口腔病理学教室におい て検索された多数の本腫瘍の生検, 手術, 剖検材 料について病理学的立場より検討し，わが国にお ける本腫瘍の実体についていくつかの知見を加え 
得たと考えるので，その結果を報告する。

\section{II. 検索資料と方法}

資料は1938年より1972年までの35年間に東京医 科歯科大学口腔病理学教室で取り扱った腺様囊胞 癌69例で, 乙れらは本学口腔外科学教室からの生 検ならびに手術材料と病理学教室で剖検されたも のである。各資料は採取後 $10 \%$ ホルマリンで固定 し，生検材料はそのまま，手術および剖検材料に ついてはできるだけ多くの個所より組織片を切り 出し, 通法の如くパラフィン包埋を行い, 組織切 片を作製した。な扔，一部は大割切片標本とし た。染色はへマトキシリン・エオジン染色を主と し, 必要に応に PAS反応（唾液消化を含む），ム チカルミン染色, アルシアンブルー染色, コロイ ド鉄染色，エラスチカ・ワンギーソン染色，アザ ンマロリー染色，鍍銀染色（渡辺法）などを行っ た。

\section{III. 所 見}

\section{1. 臨床的事項}

表 1 検索資料の年齢分布と性別

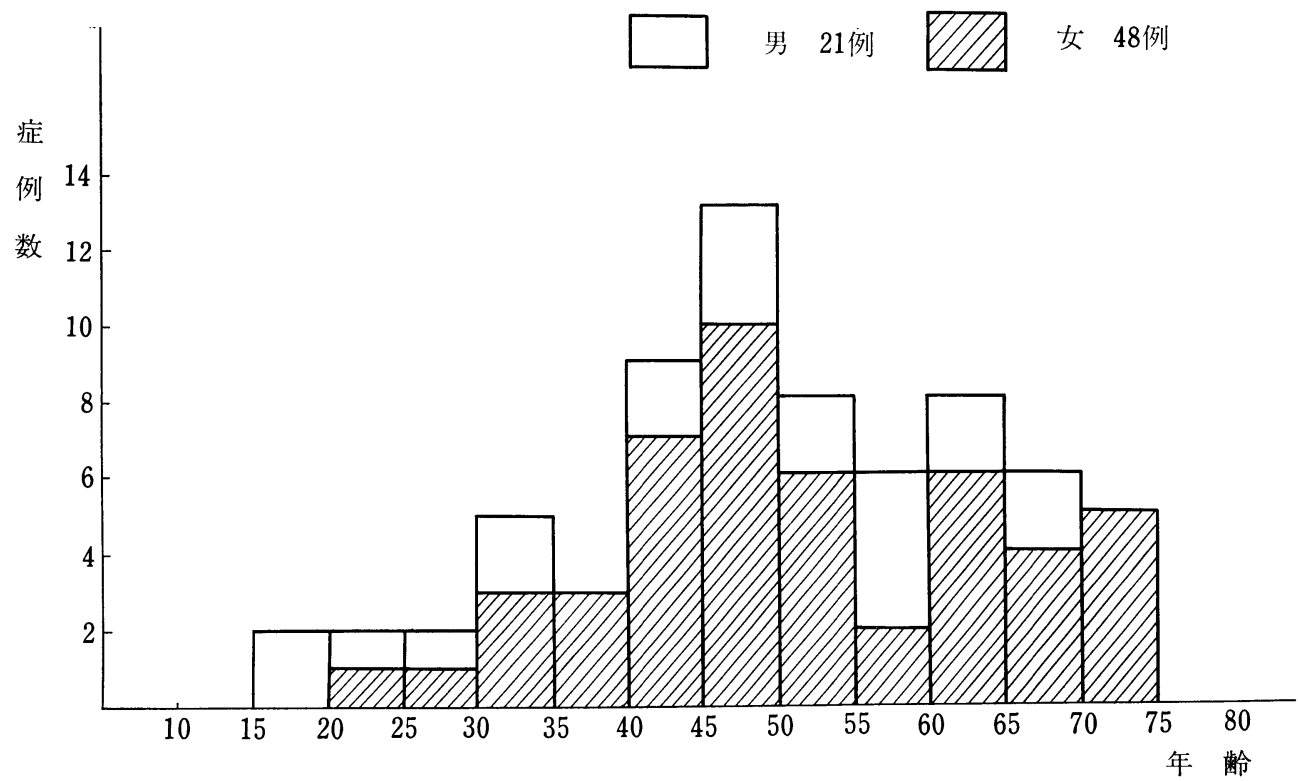


表 2 腫瘍の発現部位

\begin{tabular}{|c|c|c|c|}
\hline 口 & & 蓋 & 23 例 $(33.3 \%)$ \\
\hline 口 & & 底 & 16例 $(23.2 \%)$ \\
\hline 顎 & 下 腺 & 部 & 10例 $(14.5 \%)$ \\
\hline 上 & 口 & 唇 & 5 例 $(7.2 \%)$ \\
\hline 的 & 後 & 部 & 5例 \\
\hline & 舌 & & 5例 \\
\hline 頓 & & 部 & 3 例 $(4.3 \%)$ \\
\hline 上 & $\begin{array}{l}\text { 顎 洞 } \\
\text { 計 }\end{array}$ & 部 & $\begin{array}{l}2 \text { 例 }(2.9 \%) \\
69 \text { 例 }\end{array}$ \\
\hline
\end{tabular}

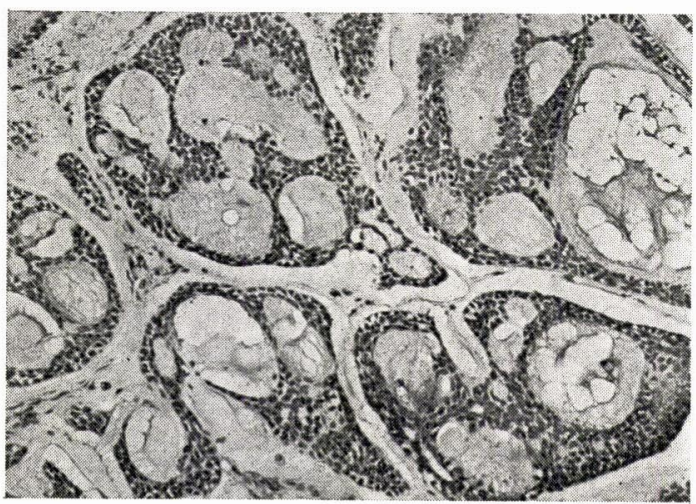

図 1 定型像

胞巣内に囊胞状腔の形成があり特徴的な節状 構造定示す。

A-69. S. H., 38歳, 女, 口底部。

No. 49509 H. E. $\times 100$

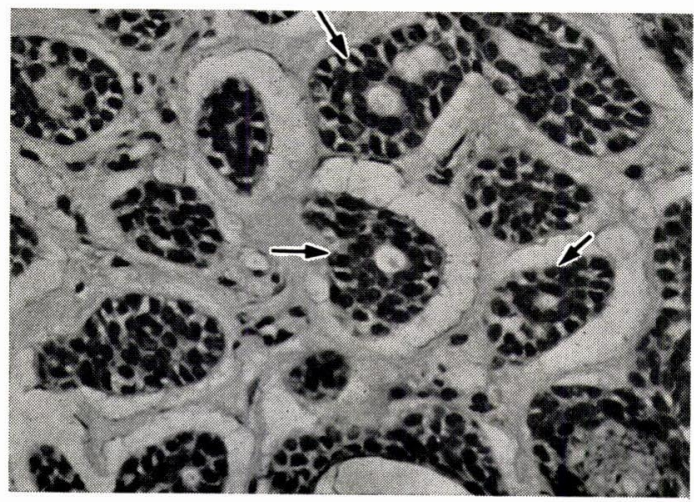

図 2 胞巣内の小腺管状腔 (矢印) の形成 A-69. S. H., 38歳, 女, 口底部。 No. 49509 H. E. $\times 300$
質に小腺管状腔が認められる（図 2)。時に腫瘍 細胞の多形性はみられるが，異型性は明らかでな い。

囊胞状腔は大きさ，形がさまざまで，一般に好 塩基性で, 時に軽度の好酸性を示す無構造な粘液 様物が認められる。組織化学的に, これらはPAS 反応で弱陽性（厜液に消化されず），ムチカルミ ン染色ならびにアルシアンブルー染色で陽性, コ ロイド鉄染色で青染した。鍍銀標本では，囊胞状 腔には好銀性の微細な網状構造と好銀細線維の腔 中央への凝集像がみられた。時に囊胞状腔内の好 銀線維は間質の好銀線維と連続していた。

小腺管状腔は 1 ないし 2 層の立方状の細胞で囲 まれており，乙れらの細胞は好酸性で，核は類円 形でクロマチンは疎で，核小体は比較的明瞭であ る。小腺管状腔には時にエオジンにやや濃染する 無構造均一な, あるいは顆粒状の粘液様物をみ る。組織化学的には，これらは PAS 反応に陽性 (医液に消化されず)で，ムチカルミン染色，アル シアンブルー染色ならびにコロイド鉄ではほとん ど染色されない。鍍銀標本では粘液様物が微細顆 粒状を呈した。

間質は一般に乏しく，柾性線維性結合組織であ るが，ところにより高度の硝子化をみる。間質の 硝子化が著しい部では，実質は一般に少なく，小 さな索状増殖を示している(図 3 )。組織化学的に 硝子化した間質は PAS 反応強陽性（唾液に消化 されず)，ムチカルミン染色，アルシアンブルー 染色にほとんど染まらず，コロイド鉄染色では淡 青橙色であった。またこの部はエラスチカ・ワン ギーソン染色では淡橙色，アザンマロリー染色で 淡青色であった。鍍銀染色では一様な褐色調を呈 した。

b. 非定型像を呈する例

残り 35 例（男 9 例，女26例）では定型的な本腫 瘍の像を示す部分とともに，他の型の睡液腺腫瘍 との鑑別が問題となる部分がかなりみられた。こ れら症例の主な非定型的組織像は次の如くであ る。

1）腫瘍組織は一見, 多形性腺腫の一型に類似 
している。実質は類円形の核を有する腫瘍細胞の 索状あるいは塊状増殖よりなり，囊胞状構造は明 らかでなく，2 層の立方状細胞で囲まれた種々の 形の腺管状構造を形成している(図 4)。腺管状腔 内には好酸性の無構造物を含むものもあり，乙れ らは，PAS 反応強陽性で，ムチカルミン染色， アルシアンブルー染色にはほとんど染色されな い。腫瘍細胞の異型性はない。間質は硝子化した 結合組織で，実質との境界は明らかであった。

2）腫瘍実質は類円型の核を有し 2 列に配列し た小型の細胞が索状に増殖し，一見，基底細胞腺 腫類似の構造を示す(図 5 )。核のクロマチンは中 等度量で核小体は不明瞭で，細胞の異型性はな い。間質は踈な線維性結合組織で全体に軽度に硝 子化している。

3）腫瘍実質は類円形の核を有する多角形の細 胞の比較的疎な配列よりなり，腫瘍細胞は大きな 立実性胞栄を形成しているが，胞㮺の一部に 1 な いし 2 層の立方状あるいは扁平な細胞で用まれた 大きな囊胞状構造を有する。この囊胞状腔内には エオジンに淡染する無構造物をみるものもあり， これはPAS反応陽性（哽液に消化されず），ム千 カルミン染色,アルシアンブルー染色陰性であり, 腺管状構造の内腔が拡大したものと考えられる。 腫瘍細胞には異型性は明らかでない。間質は線維

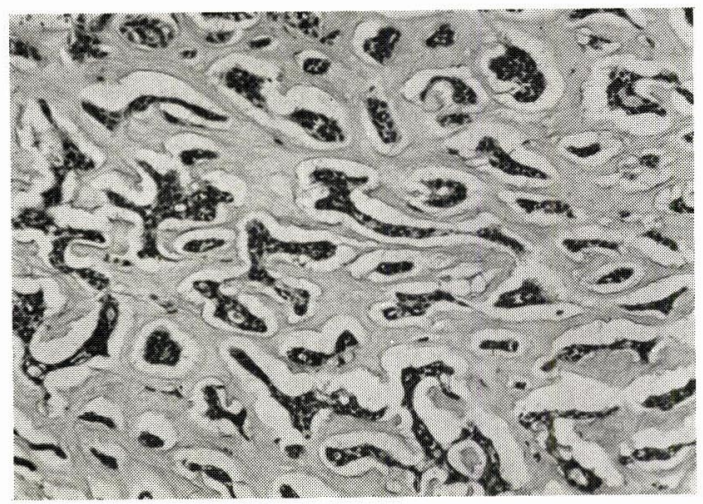

図 3 小胞巣の索状浸潤性増殖。間質の硝子化が著 しい。 A-35. O. K., 62歳，女，口蓋。 No. 29695 H. E. $\times 120$
性結合組織で硝子化は著しくほない(図 6)。

4）実質は多角形の細胞が比較的充実性に増殖 し，大小の胞栄を形成している(図 7)。腫瘍細胞 の核はやや大きく, 類円形ないし楕円形で， クロ マチンは中等量で，核小体は明らかでない。細胞 の多形性は多少みられるが異型性は一般に明らか でない。胞栄内には小腺管状構造を散見し，乙れ を囲む一層の細胞を区別しうる。乙れら小腺管状 腔内には内容物はほとんどみられないが，時にエ

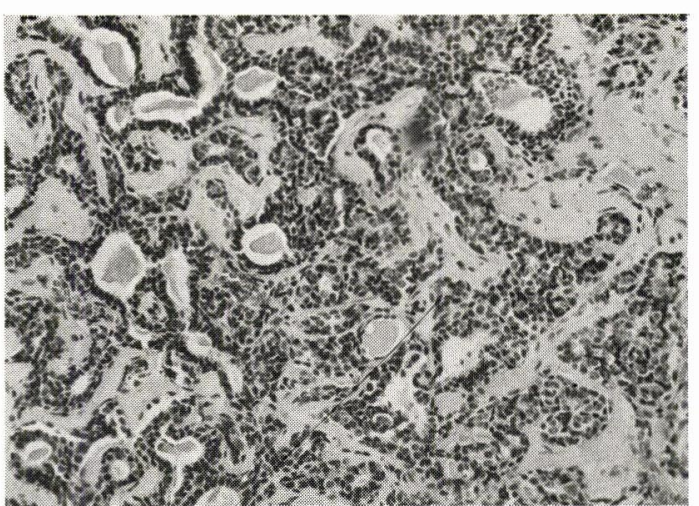

図 4 非定型像

囊胞状構造は明らかでなく，実質は腺管腔状 構造を呈し，一見多形性腺腫様である。 A-3. I. T., 46歳, 男, 口蓋。 No. 5929 H. E. $\times 120$

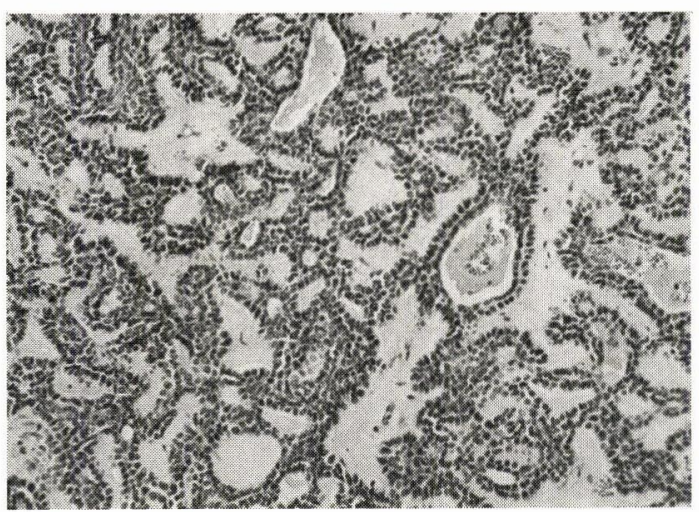

図 5 非定型像

腫瘍細胞は索状に増殖し，一見基底細胞腺腫 様像老示玄。

A-15. U. S., 47歳，女，上顎洞。

No. 12837 H. E. $\times 120$ 
オジンにやや濃染し，PAS 反応陽性（烸液に消 化されず）の粘液様物をみ，乙れらはムチカルる ン染色ならびにアルシアンブルー染色では陰性で あった。また，胞巣内には少数ながら小囊胞状腔 もみとめられ，乙れら内腔にも小量の粘液様物を 含み，PAS 反応陰性で，ムチカルミン染色弱陽 性で，アルシアンブルー染色に陽性であった。間 質は細胞と線維成分の少ない粘液性成分に富んだ 疎な線維性結合組織で，アルシアンブルー染色に 陽性であった。

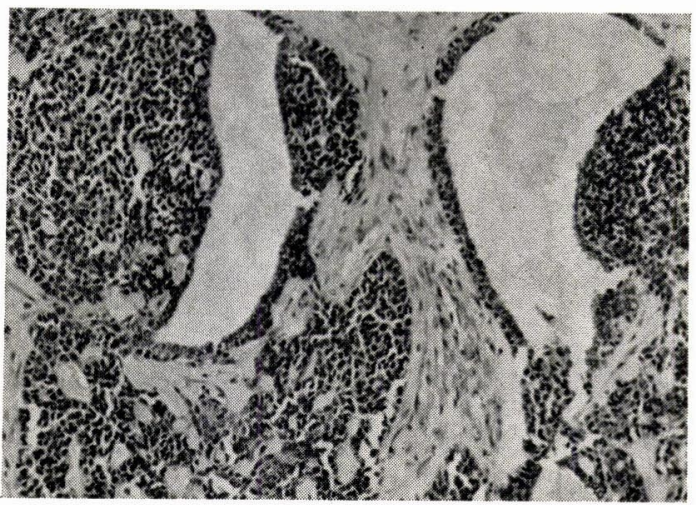

図6 非定型像

充実性胞巣の一部に大きな囊胞状構造を示す。 A-47, T. K., 45歳, 女, 舌。

No. 36655 H. E. $\times 120$

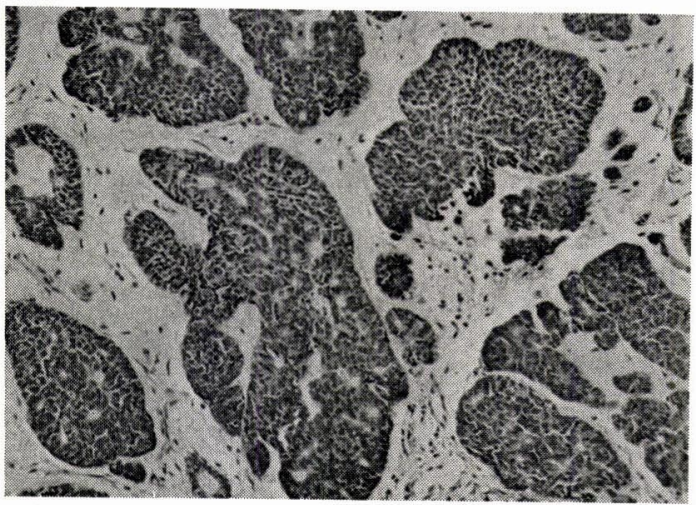

図 7 非定型像

胞体，核のやや大きな細胞の比較的充実性増 殖よりなる胞巣が散在。

A-68, Y. T., 35歳, 男, 口蓋。

No. 49482 H. E. $\times 120$
5）実質は多角形の細胞が比較的大きな胞栄を 形成しながら充実性に増殖し, 胞巣の中心部に壊 死像をみる。腫瘍細胞ならびに円形の核はやや大 きく，核小体も比較的明瞭で，クロマチンもやや 多い。腫瘍細胞には多形性ならびに異型性も認め られる(図 8 )。胞巣内には小腺管状構造は散見さ れるが，内容物はほとんどみられない。間質は線 維性結合組織で, 実質との境界は明瞭であった。 このような組織像は一見，乳腺における面ぽう癌 を思わせる。

6）腺管状構造の形成が著明で, 管状腺癌に類 似する像を示すもので，実質の一部が腺管状に増 殖したり，あるいはさまざまな大きさの不規則な 腺管状構造を形成している像もみられた(図 9)。 これらは 1 ないし 2 層の立方状細胞の腺管状増殖 で，腫瘍細胞の胞体はやや好酸性で，核は類円形 または楕円形，クロマチンはそれ程多くない。核 小体は時に 1 ないし 2 個明瞭なものもある。細胞 の異型性も軽度にみられた。時に管腔内にエォジ ンに淡染し，PAS 反応陽性（唾液に消化され ず)，無構造な粘液様物をみる。これらはムチカ ルミン染色，アルシアンブルー染色で陰性であっ た。間質は線維性結合組織からなっている。

C. 発現部位と組織像

発現部位別には定型像が主体をなす症例は表 3

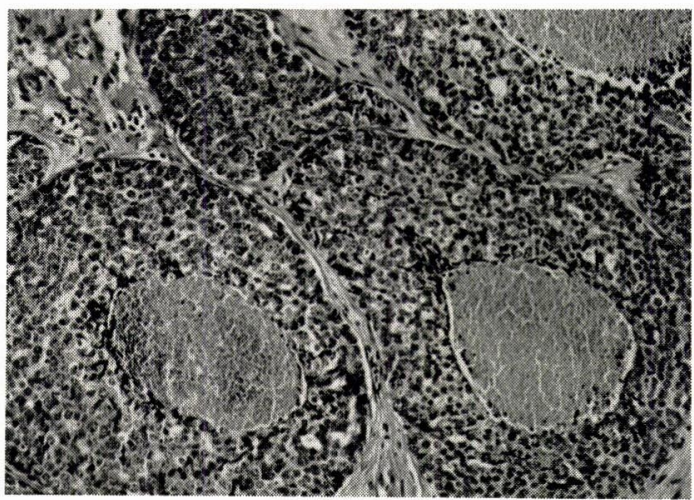

図 8 非定型像

大きな胞巣を形成し，胞巣中心部に壊死像を み, 一見面ぽう癌様像を示す。

A-59. S. H., 52歳, 女, 臼後部。

No. 45291 H. E. $\times 120$ 


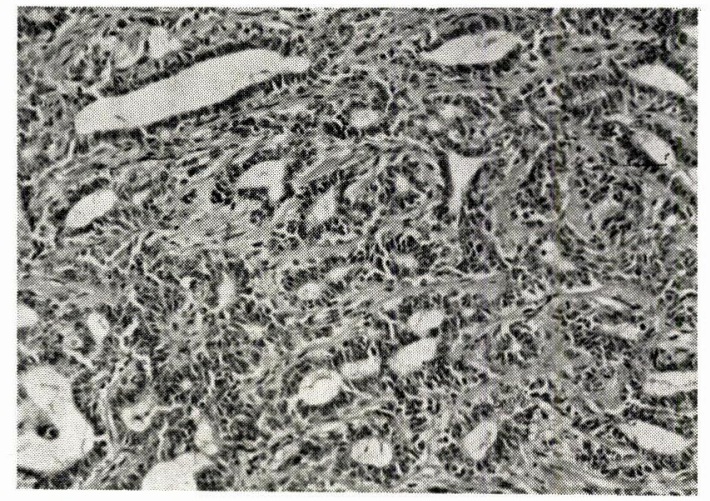

図 9 非定型像

大小さまざまの腺管状構造があり，一見管状 腺癌様像を示す。

A-47. T. K., 45歳, 女, 舌。

No. $36655_{-2}$ H. E. $\times 120$

\section{表 3 発現部位と組織像}

\begin{tabular}{|c|c|c|c|c|c|}
\hline \multicolumn{3}{|c|}{ 発 現 部 位 } & \multicolumn{2}{|c|}{ 全症例数|定型像が主价症例 } & \multirow{2}{*}{$\begin{array}{c}\text { 非定型像が主 } \\
\text { 例 } \\
14 \text { 例 }\end{array}$} \\
\hline 口 & & 蓋 & 23例 & 9例 & \\
\hline 口 & & 底 & 16 & 11 & 5 \\
\hline & 下 腺 & 部 & 10 & 4 & 6 \\
\hline 上 & 口 & 唇 & 5 & 3 & 2 \\
\hline 臼 & 後 & 部 & 5 & 2 & 3 \\
\hline & 舌 & & 5 & 1 & 4 \\
\hline 煩 & & 部 & 3 & 3 & 0 \\
\hline & 顎＼cjkstart洞 & 部 & 2 & 1 & 1 \\
\hline & 計 & & 69 & 34 & 35 \\
\hline
\end{tabular}

の如く, 煩, 口底, 口唇に生じた例に多い。非定 型像が主体をなす症例は舌, 口蓋, 臼後部に生じ た例で比較的多い。上顎洞と口蓋に生じた例では 管状腺癌様像あるいは充実性增殖像が多かった。

\section{d. 周囲組織への増殖状態}

腫瘍法周囲組織へ浸潤性に増殖し, 組織学的に 腫瘍組織と周囲組織間に被膜形成はみられない （図10）。下記の 3 症例は手術材料を大割切片標本 とし腫瘍組織の増殖状態を観祭した所見である。

症例 1 (A-66) I. T., 42歳, 女。発現部位: 口 底部。患者は来院約 6 力月前より左口底部の無痛 性腫脹に気付く。来院時腫脹は口底の正中部より 6部に抢よび，弾性硬で境界明瞭であった。同部 からの生検後, 左口底部と同側の舌の一部, $\overline{3}$ 上
り左下顎角部におよぶ下顎骨，両側顎下腺ならび に雨側舌下腺の摘出術と左頸部廓清術が行われ た。肉眼的には腫瘍は口底にあり， 5 部を中心に 正中部から 6 相当部にまで拡がっており，表面の 一部は潰瘍状であった。 5 部煩舌方向断面切片標 本では, 腫瘍組織は下顎骨舌側部に大きな塊状を なして増殖していた(図11)。腫瘍と周囲組織との 境界は比較的明膫であるが，腫瘍組織は舌側の筋 組織間結合組織内に浸潤増殖していた。腫瘍は下

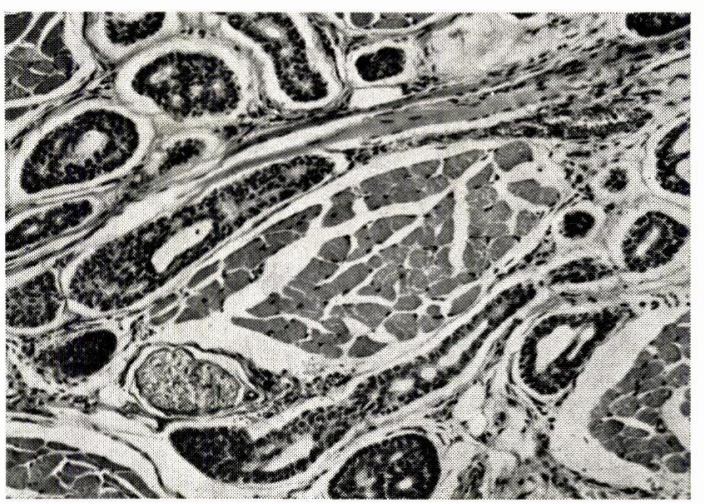

図10 腫瘍組織の舌筋内への浸潤性増殖像 A-47. T. K., 45歳, 女, 舌。 No. $36655-2$ H. E. $\times 120$

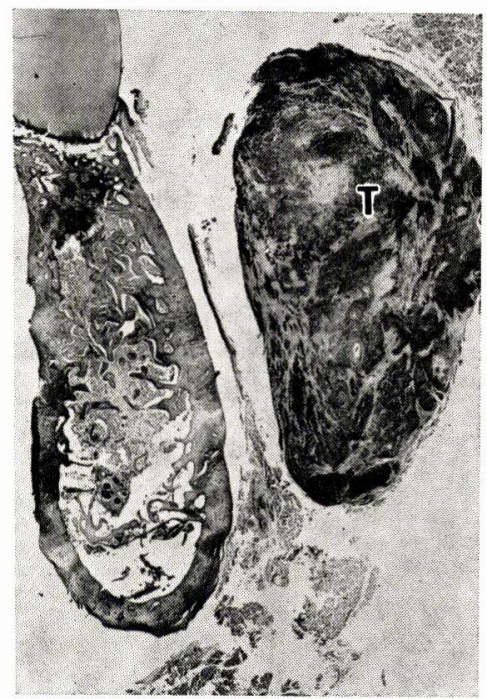

四11 5 部頓舌的切片標本全体像 左が頓側，右が舌側，Tは腫瘍。 A-66. I. T., 42歳, 女, 口底部。 No. 48504-7 H. E. $\times 2.3$ 
顎骨両断端面には組織学的にも認められなかった が， 3 直下の骨体内骨髄に腫瘍組織の浸潤性増殖 が認められた(図12)。両側顎下腺ならびに舌下腺 には腫瘍組織はみられなかった。リンパ節は 5 個 を組織学的に検索し, 中深頸リンパ節 1 個にのみ 転移を認めた（頸部廓清の項参照）。腫瘍の組織 像はいずれも充実型の非定型像が主であった。

症例 2(A-68) Y. T., 35歳, 男。発現部位: 口蓋。患者は約 1 年前より口蓋の腄脹に気付く。 来院時腫脹は右側硬口蓋全体に及び $4.0 \times 3.0 \mathrm{~cm}$ 大で正中を $1 \mathrm{~cm}$ 位越えていた。生検後, 右口蓋 切除術と在頸部廓清術が行われた。肉眼的には手 術材料は 1 から 7 を含む右口蓋で $2.0 \times 3.0 \times 1.0$ $\mathrm{cm}$ 大の腫瘤があり, 中央部に $0.6 \times 1.2 \mathrm{~cm}$ 大の

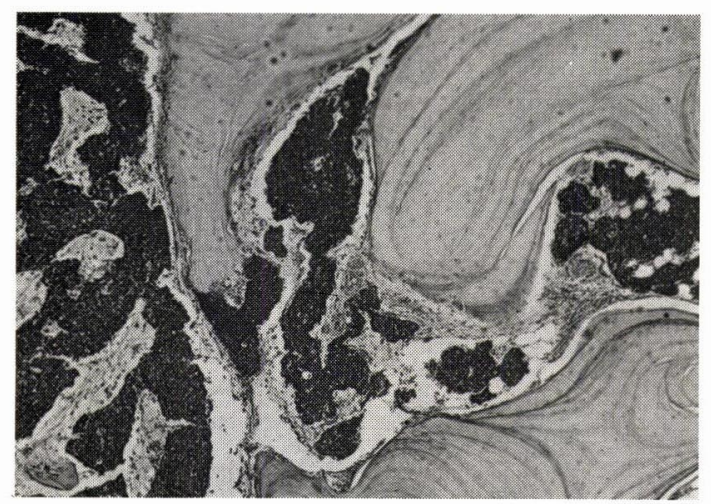

図123部骨髄内の腫瘍の浸潤性増殖像 A-66. I. T., 42歳, 女, 口底部。 No. $48504_{-9}$ H. E. $\times 50$
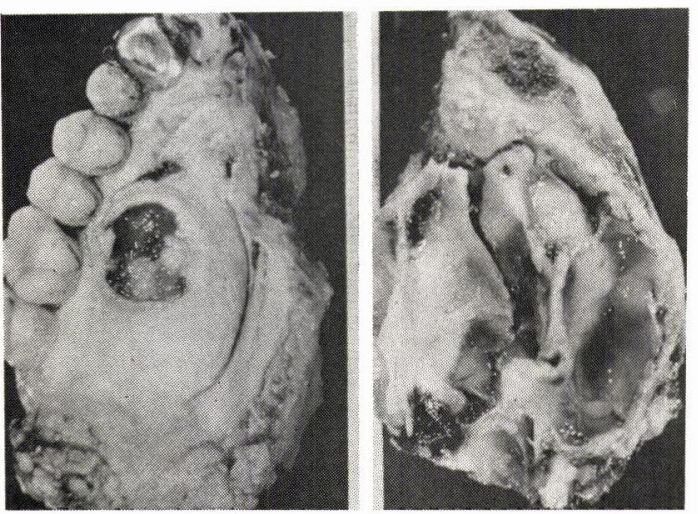

図13 摘出物全体像

A-68. Y. T., 35歳, 男, 口蓋
潰瘍を伴っていた(四13)。手術材料の上面は鼻腔 と上顎洞底で，両者の境界部に $1.2 \times 1.6 \mathrm{~cm}$ 大の 骨膨隆をみた。標本は口蓋正中線に直角の面で切 り作製した。6 近心部断面では, 腫瘍は口蓋のほ ぼ全体を占め 6 口蓋側部から正中部近くにまで増 殖し，鼻腔の粘膜下にまで及んでいた（図 14）。 6|口蓋側菌槽骨は吸収され(図15)，また口蓋の潰 瘍部では腫瘍組織が露出していた。 7 中央部断面 では腫瘍は口蓋から鼻腔底にかけ増殖し，また腫

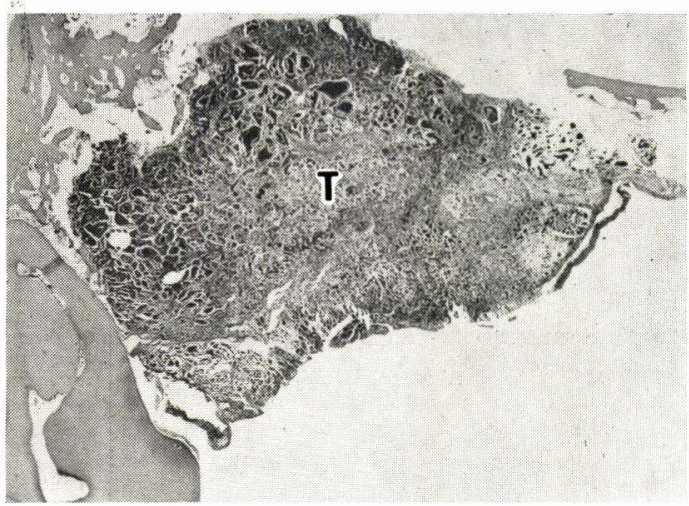

図146 近心断面の切片標本全体像。Tは腫瘍 A-68. Y. T., 35歳, 男, 口盖。 No. $50157_{-4}$ H. E. $\times 2.3$

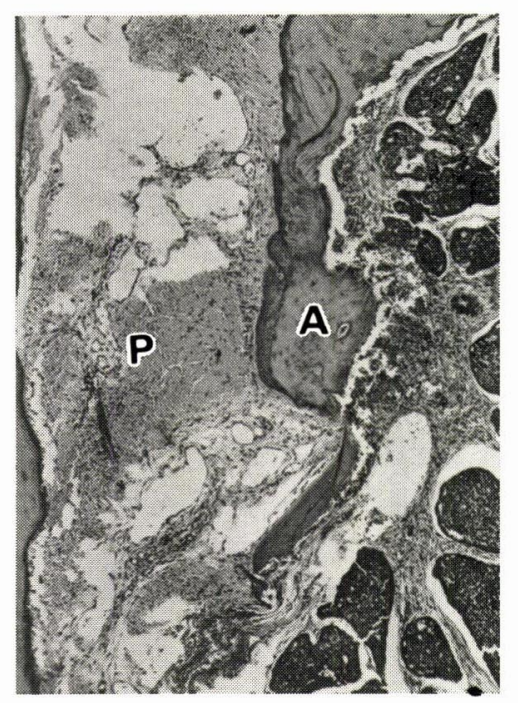

図15 前図の一部拡大像。6 口盍側菌槽骨部 A は歯槽骨, Pは歯根膜 A-68. Y. T., 35歳, 男, 口盍。 No. $50157_{-4}$ H. E. $\times 50$ 
瘍組織は一部上顎洞底部から洞腔内へ突出してい た(図16)。腫瘍組織は壊死を伴った充夹性増殖像 であった。腫瘍は前, 後, 正中断端部には認めら れなかった。リンパ節は計 25 コを組織学的に検索 し, 右顎下部に 2 コ, 顎二腹筋内側に 1 コ, 計 3 コに転移を認めた（頸部廓清の項参照）。

症例 3（A-73） M. C., 55歳，女。発現部位： 臼後部。患者は来院約 3 年前より左臼後部に無痛 性の腫脹を自覚。2 年前動摇のため $4-8$ の雪牙 を抜去。6 カ月位前より左臼後部の腫脹著しくな る。来院時左臼蔝部菌肉より煩粘膜にびまん性の 腫脹があり，下顎角部にも骨様硬の腫脹がみられ た。生検後，4 から左関節頭までの下頂骨ならび に左口底と舌の一部を含む摘出術と左頸部廓清術 が行われた。手術材料では左臼後部歯肉から制部 に灰白色の腫瘍の增殖があった(図17)。摘出下顎

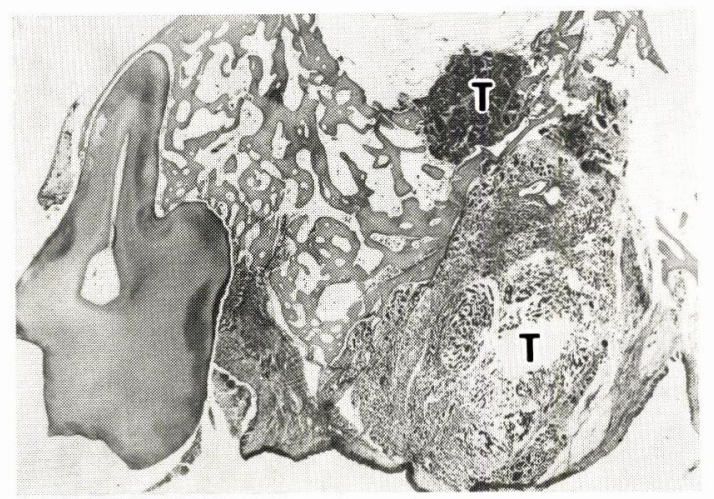

図16 7 部切片標本全体像。腫隍の上顎洞内への 突出。Tが腫瘍。

A-68. Y. T., 35歳, 男, 口蓋。

No. $50157_{-6}$ H. E. $\times 2.3$

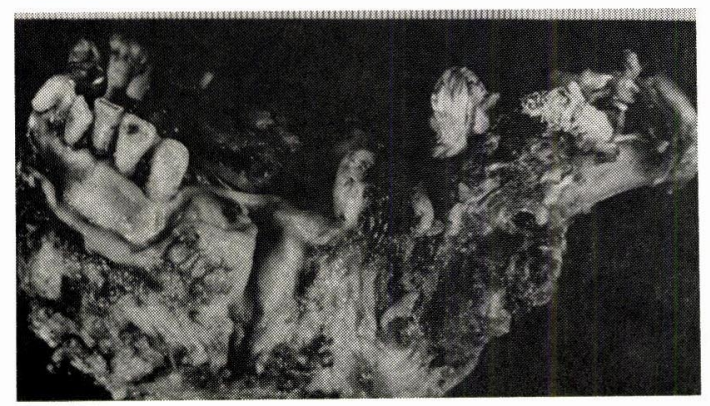

図17 摘出物全体像

A-73. M. C., 55歳, 女。
骨流煩舌的に切り組織標本とした。曰後部では， 下顎骨内部に腫瘍組織の広汎な浸潤性増殖があ り，歯槽部骨組織ならびに煩舌側骨皮質の一部は 破壊消失していた(図18)。腫瘍組織は摘出下顎骨 体内に広汎に浸潤増殖しており，浸潤は関節突起 の先端部近くから 拡がっていた(図19)。さらに腄瘍組織は骨髄から 口底, 舌一も高度に浸潤增殖していた(図20)。腫 瘍は組織学的には立奏性增殖像を主とした非定型 像で，胞巣中心部に壊死を伴っていた。

e．神経ならびに骨組織への浸潤状態

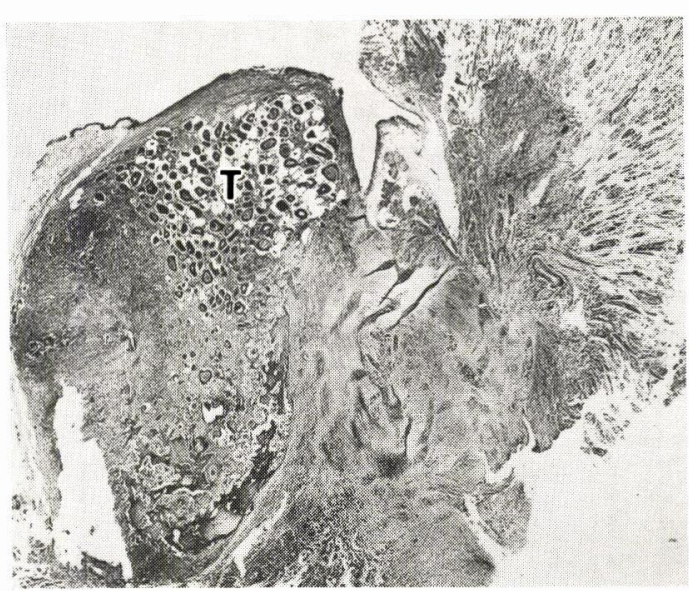

図18 左臼後部煩舌的切片標本全体像 左が煩側，右が舌側，Tは顎骨内の腄瘍。 A-73. M. C., 55歳, 女, 臼後部。 No. 52930 H. E. $\times 2.5$

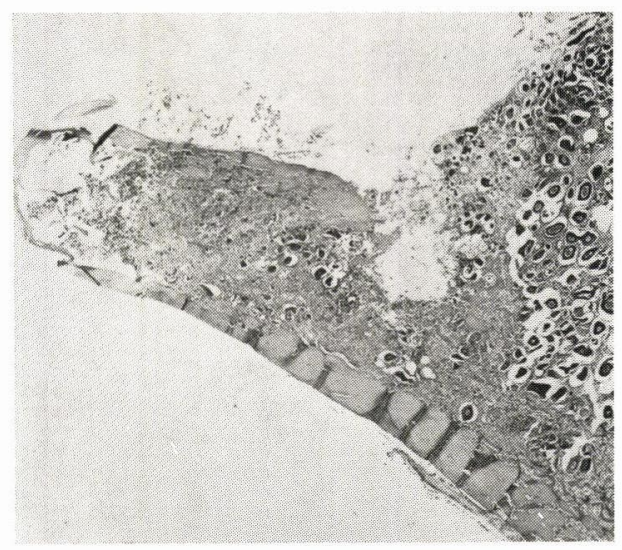

四19 左下顎関節頭部切片標本全体像

A-73. M. C., 55歳，女，臼後部。

No. 52930 H. E. $\times 2.5$ 


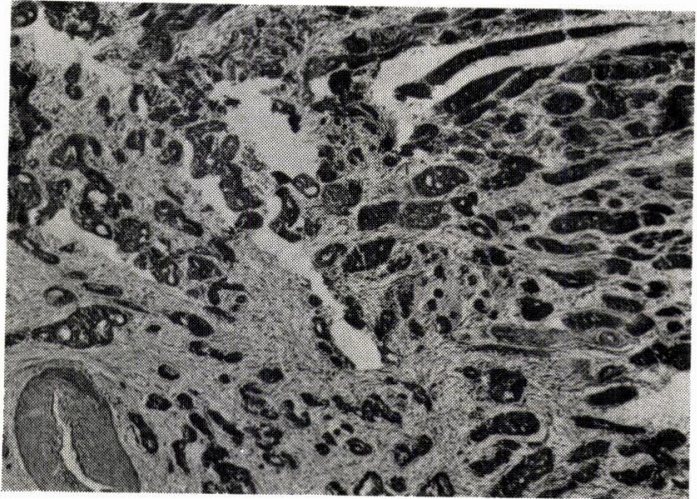

四20四18の一部拡大像

周囲結合組織内への浸潤像著明。

A-73. M. C., 55歳, 女, 臼後部。

No. 52930 H. E. $\times 50$

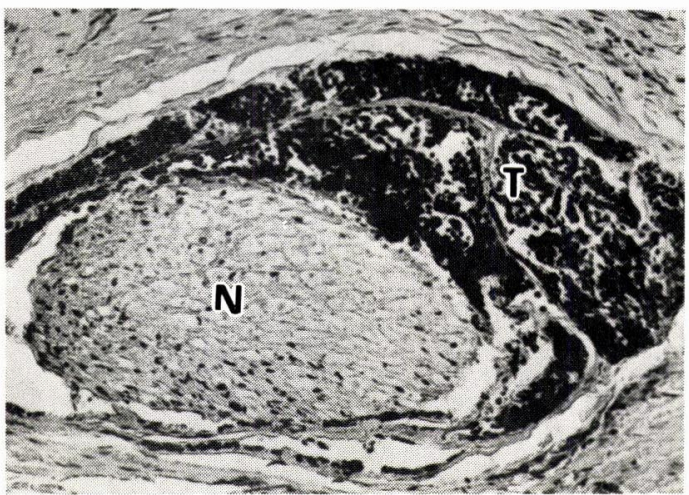

図21 神経線維周囲の浸潤性増殖像 Tは腫瘍, Nは神経

A-9. K. T., 49歳, 女, 舌。

No. 6504 H. E. $\times 150$

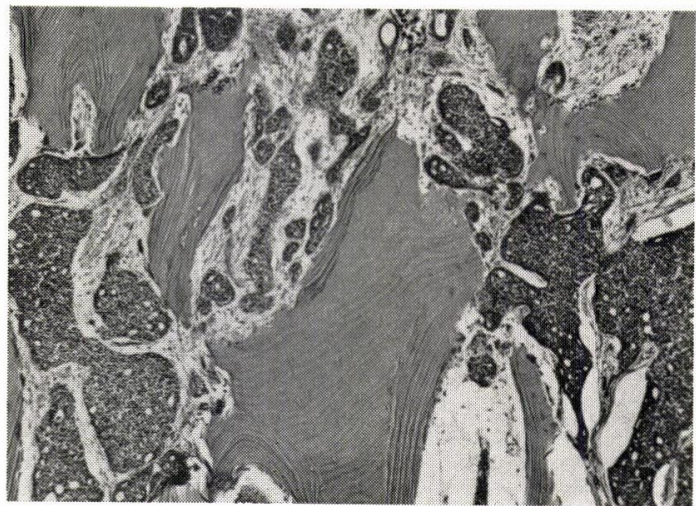

図22 腫瘍組織の下顎骨への浸潤増殖像

A-73. M. C. 55歳，女，臼後部

No. 52930 H. E. $\times 50$
69例の検索例中 25 例 $(36.3 \%)$ の標本内で神経 線維束周囲あるいは内に腫瘍組織の浸潤性増殖像 が認められた（図21）。神経周囲に腫瘍の浸潤を みた例は表 4 の如く，発現部位別には著しい差は ない。またこれら25症例中定型例は13例（定型例 全体の38.2\%), 非定型例は12例(非定型例全体の $34.3 \%$ ）で両者間に有意差はない。

本腫瘍は顎骨骨髄内への浸潤性増殖も稀ではな い。前記の症例 3 の如く広汎な拡がりを示す例も あるが，本検索例中には10例（全体の14.5\%）で 顎骨内浸潤が認められた。全般に骨髄内に浸潤増 殖した腫瘍組織は扁平上皮癌などに比し骨の破壊 は比較的弱い(瓯22)。乙れら10例の発現部位は口 莣 5 例（口蓋例全体の $21.7 \%)$, 口底 1 例（6.3 $\%)$, 顎下腺部 2 例 $(20 \%)$, 臼後部 1 例(20\%),

上顎洞部 1 例 $(50 \%)$ で，上顎洞部に生じた例で 最も多かった。腫瘍の組織像は定型例が 3 例（定 型例全体の7.5\%), 非定型例 7 例 $(24.1 \%)$ と非 定型例に多い。

\section{3. 転移について}

a．頸部リンパ節転移

臨床的に頸部リンパ節の転移が疑われ, 頸部廓 清術を行い組織学的に検査した症例は9例あり, それらの主な所見は，表 5 の如くである。これら 9 例中 1 例 $(\mathrm{A}-22)$ 以外は来院, 生検後約 1 力月 前後に原発部位の应汎な切除と同側の頸部廓清術 を受けている。1例（A-22）は口蓋に生した腫瘍 切除の 2 年後に再発し, 上顎骨の半摘出と, 頸部

表 4 神経周囲に腫瘍の浸潤を みた例の原発部位別数

\begin{tabular}{|c|c|c|c|c|c|}
\hline 発 & 現 部 & 位 & 全症例 & \multicolumn{2}{|l|}{ 浸潤例 } \\
\hline 口 & & 蓋 & 23例 & 8例 & $34.8 \%$ \\
\hline 口 & & 底 & 16 & 8 & 50 \\
\hline 顎 & 下 腺 & 部 & 10 & 1 & 10 \\
\hline 上 & 口 & 唇 & 5 & 2 & 40 \\
\hline$F$ & 後 & 部 & 5 & 2 & 40 \\
\hline & 舌 & & 5 & 2 & 40 \\
\hline 煩 & & 部 & 3 & 1 & 33.3 \\
\hline 上 $\frac{\mathrm{n}}{5}$ & 顎＼cjkstart洞 & 部 & 2 & 1 & 50 \\
\hline & 計 & & 69 & 25 & \\
\hline
\end{tabular}


表 5 頸 部 郭 清 例

\begin{tabular}{|c|c|c|c|c|c|c|c|}
\hline & 症例 & 年齢 & 性 & 発現部位 & $\begin{array}{l}\text { 発症後手手 } \\
\text { 期で間 }\end{array}$ & $\begin{array}{l}\text { 転移リン } \\
\text { ㅇ 節 数 }\end{array}$ & 予 \\
\hline 1 & A-22.O.K & 50 & 女 & 口 蓋 & 1 年 & $1 / 10$ & \\
\hline 2 & A-47.T.K & 45 & 女 & 舌 & 1 年 & $1 / 4$ & \\
\hline 3 & A-56.M.Y & 51 & 女 & 口底 & 7 年 & $3 / 13$ & \\
\hline 4 & A-66. I.T & 42 & 女 & 口 底 & 6 力月 & $1 / 5$ & \\
\hline 5 & A-68.Y.T & 35 & 男 & 口蓋 & 3 力月 & $3 / 25$ & \\
\hline 6 & A-73.M.C & 55 & 女 & 臼後部 & 3 年 & $2 / 7$ & \\
\hline 7 & A-58.Y.Y & 67 & 男 & 口底 & 4 年. & $0 / 10$ & \\
\hline 8 & A-59.S.H & 52 & 女 & 臼後部 & 1 年 & $0 / 6$ & \\
\hline \multirow[t]{2}{*}{9} & A-65.A.R & 27 & 女 & 臼後部 & 4 年 & $0 / 7$ & \\
\hline & \multicolumn{6}{|c|}{ 表 6 頸部リンパ節転移確認例の発現部位別症例数 } & \\
\hline \multicolumn{3}{|c|}{ 発 現 部 位 } & \multicolumn{2}{|c|}{$\begin{array}{l}\text { 頸部リソパ節 } \\
\text { 転 移確認例 }\end{array}$} & \multicolumn{3}{|c|}{$\begin{array}{l}\text { 全症例数に } \\
\text { 詨割合 }\end{array}$} \\
\hline \multirow{2}{*}{ 口 } & & 蓋. & \multicolumn{2}{|r|}{ 2例 } & \multicolumn{3}{|c|}{$8.7 \%$} \\
\hline & 1 & 底 & & 2 & \multicolumn{3}{|c|}{12.} \\
\hline \multirow[t]{2}{*}{ 且 } & 後 & 部 & & 1 & \multicolumn{3}{|c|}{20.0} \\
\hline & 舌 & & & 1 & & 6.7 & \\
\hline
\end{tabular}

廓清術を受けた。またとれら 2 度の手術間に放射 線治療もうけていた。

これら 9 例中 6 例で頸部リンパ節転移を組織学 的に確認した。転移を認めた 6 例の発現部位と, それぞれの部位に扔ける全症例との割合は表 6 亿 示した。頸部リンパ節転移は臼後部に生じた例で 最も多かったが, 症例数が少ないので確定的なこ とは言い得ない。

組織像は, 頸部リンパ節転移をみた 6 例共原発 栄, 転移栄の両者で腺様囊胞癌としての定型像よ り非定型像を示す部位が多かった(図23)。原発部 位抢よび転移栄での腫瘍の組織像は充実性胞巣状

四23 リンパ節転移像
A-56. M. Y., 51歳, 女, 口底。
No. 42406 H. E. $\times 50$

増殖像ならびに管状腺癌樣像が比較的多い。転移 を認め得なかった 3 例の原発部位に抢ける組織像 は，2 例は定型像を示す部が非定型像の部より多 かった。

b. 遠隔転移 (剖検例)。

剖検例は 4 例で, これらの概略は表 7 亿示し 
表 7 剖 検 例

\begin{tabular}{|c|c|c|c|c|c|c|c|c|}
\hline & 年 歯令 & 性 & 部 & & 位 & 全経過 & 主 治療 & 移 \\
\hline 1. $\mathrm{Y} \cdot \mathrm{T}$ & 26 & 男 & 口 & & 蓋 & 5 年 8 カ月 & 外? & 脳, 肺, 肝, 副㹂, 前立腺 \\
\hline 2. S.M & 49 & 男 & 顎 & 下 & 腺 & 4 年 6 力月 & 放. 化 & $\begin{array}{l}\text { 肺, 胸膜, 肝, 腎, 皮下, 腰椎; 頸部リ } \\
\text { 節 }\end{array}$ \\
\hline 3. M. K & 40 & 女 & & 舌 & & 8 年 4 力月 & 放. 外 & 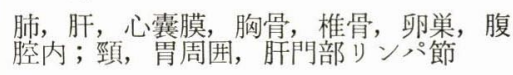 \\
\hline 4. I. K & 58 & 男 & & 口 & 唇 & 12年 & 外. 放 & $\begin{array}{l}\text { 脳底部, 肺, 晘, 頸椎, 胸椎 } \text {; 頸部, 気 } \\
\text { 管周囲リソハ節 }\end{array}$ \\
\hline
\end{tabular}

た。発現部位はそれぞれ異なっていた。性別は男 性 3 例, 女性 1 例で, 剖検時の年柃注比較的若 い。全経過は 4 年 6 力月から 12 年に及び，いずれ も比較的長い。いずれの症例もこの間に局所再発 を繰り返し各種の治療を受けていた。経過中 2 例 目，3例目では肺転移がX線的に認められてお り，3 例目，4 例目では椎骨への転移が認められ ていた。剖検時いずれも局所は外科的切除後ある いは放射線照射後の状態で， 2 例目以外は局所に 腫瘍の残存を認めた。 4 例共血行性あるいはリン パ行性の転移が著しく, 特に肺, 肝, 骨への広汎 な遠隔転移が認められた。

転移像は因眼的には球形の灰白色結節状を呈し （図24）, 組織爫的には腫瘍組織は, 全般的には原 発栄と転移巣間に差異はなかったが，転移巣での

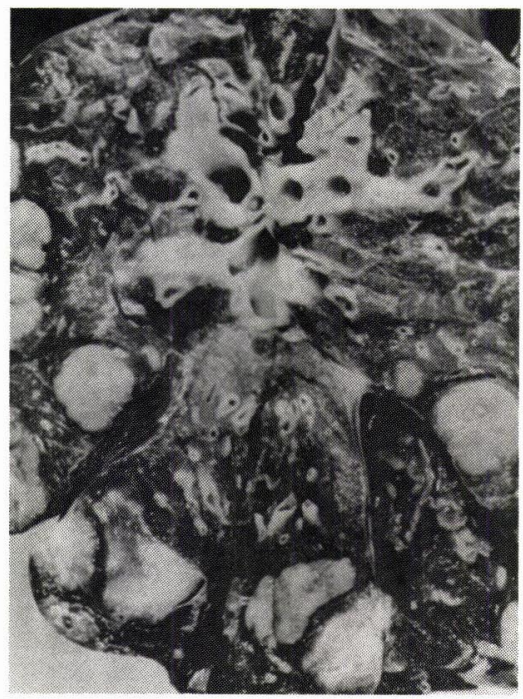

困24 肺的の結節状の転移像

剖検 3 例目，M.K., 40歳，女。原発部位：舌。
組織像は多彩で，いずれの例においても腺様囊胞 癌としての特徵像以外に, 非定型像の立実性增殖 像などが混在していた(四25)。また腫瘍細胞は全 般に転移栄の方が原発栄に比してやや大きく，異 型性もやや強い。1 例目， 2 例目では，原発巣の 腫瘍組織は小腺管状あるいは小囊胞状構造を有す る胞桕の密な増殖よりなる定型像に富み, 細胞の 異型性は認められない。転移栄では，小腺管状あ るいは小囊胞状構造を有する胞栄の密な増殖より なる定型像がみられたが, 充実性増殖の非定型像 もかなりみられた。また腫瘍細胞には異型性は明 らかでなかったが，多形性は認められた。3 例目 では，原発巣は非定型像が多く，管状腺癌状また は充実性小胞栄の索状増殖像で，核は楕円形でや や大きいが異型性は明らかでなかった。転移巣で は, 定型像もみられるが非定型像の方が多く, 充 実性増殖像が主で，一部大きな胞巣中央部に壊死 を伴っていた。核はやや大きく，形も不同で，ク ロマチンは踈で，核小体も目立つものが多い。4 例目では，原発栄は，一部に定型像もみられた

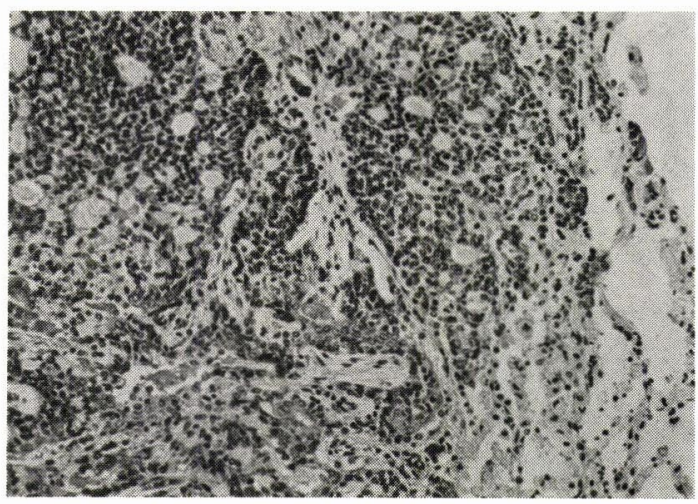

図25 肺転移巣，図24の組織像。H. E. $\times 120$ 
表 8 一次症例の再発例

\begin{tabular}{|c|c|c|c|c|c|c|c|c|c|c|c|}
\hline & \multirow{2}{*}{ 症 例 } & \multirow{2}{*}{ 年齢 } & \multirow{2}{*}{ 性 } & \multirow{2}{*}{$\mid$\begin{tabular}{|} 
発現 \\
部位
\end{tabular}} & \multirow{2}{*}{\multicolumn{2}{|c|}{$\begin{array}{l}\text { 再発治療方法 } \\
\text { 回数及び回数 }\end{array}$}} & \multirow{2}{*}{ 予 } & \multirow{2}{*}{\multicolumn{2}{|c|}{ 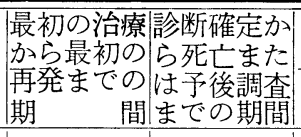 }} & \multicolumn{2}{|c|}{ 組織 } \\
\hline & & & & & & & & & & 発 現 部 位 & 再 発 部 位 \\
\hline 1 & $\stackrel{\mathrm{A}-9}{\mathrm{~K} . \mathrm{T}}$ & 49 & 女 & 舌 & 1 回 & 呼術 1 回 & $\mathrm{DC}$ & 2 年 5 力月 & 月 2 年 9 力月 & 定型像＞非定型像 & 定型像＜非定型像 \\
\hline 2 & $\begin{array}{c}\mathrm{A}-22 \\
\mathrm{O} . \mathrm{K}\end{array}$ & 50 & 女 & 口 蓋 & 2 & 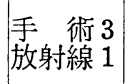 & $\mathrm{DC}$ & 5 年 & 9 年 & 定型像＜非定型像 & 定型像＜非定型像 \\
\hline 3 & $\begin{array}{l}\mathrm{A}-25 \\
\mathrm{M} . \mathrm{K}\end{array}$ & 32 & 女 & 舌 & 1 & $\mid \begin{array}{l}\text { 放射線 } 1 \\
\text { 手 } \\
\quad \text { 術 } 1\end{array}$ & $\mathrm{DC}$ & 3 年 6 力月 & 8 年 4 力月 & 定型像＜非定型像 & 定型像＜非定型像 \\
\hline 4 & $\begin{array}{c}\text { A-33 } \\
\text { S.K }\end{array}$ & 47 & 女 & 上口唇 & 2 & $\mid$\begin{tabular}{|c|} 
放射線 2 \\
術 1
\end{tabular} & $\begin{array}{c}\mathrm{DC} \\
\text { 肺転移 } \\
(\mathrm{X}-\mathrm{P})\end{array}$ & 1 年10力月 & 5 年 7 力月 & 定型像>非定型像 & 定型像＞非定型像 \\
\hline 5 & $\begin{array}{c}\text { A-46 } \\
\text { Y. I }\end{array}$ & 73 & 女 & 口 蓋 & 1 & 放射線 2 & $\begin{array}{c}\text { DC } \\
\text { 転移(不明) }\end{array}$ & 1 年11力月 & 2 年 8 力月 & 定型像＜非定型像 & 定型像 < 非定型像 \\
\hline 6 & $\begin{array}{c}\text { A-52 } \\
\text { N.K }\end{array}$ & 64 & 女 & 口 蓋 & 2 & \begin{tabular}{|c|} 
手 術 2 \\
放射線 1
\end{tabular} & $\mathrm{AC}$ & 2 年 5 力月 & 4 年 2 力月 & 定型像＜非定型像 & 定型像＜非定型像 \\
\hline 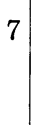 & $\begin{array}{c}\text { A-53 } \\
\text { S.H }\end{array}$ & 42 & 女 & 煩 部 & 1 & \begin{tabular}{|l|} 
手 術 2 \\
放射線 1
\end{tabular} & $\begin{array}{c}\text { AO } \\
\text { ( } 2 \text { 年11 月) } \\
\text { 前回処置後 }\end{array}$ & 2 力月 & 3 年 1 力月 & 定型像＞非定型像 & 定型像＜非定型像 \\
\hline 8 & $\begin{array}{c}\text { A-66 } \\
\text { I.T }\end{array}$ & 42 & 女 & 口 底 & 1 & $\begin{array}{c}\text { 手 術 } 1 \\
\text { 放射線 } 1\end{array}$ & $\mathrm{DC}$ & 2 力月 & 1 年 6 力月 & 定型像＜非定型像 & 定型像＜非定型像 \\
\hline y & $\begin{array}{l}\text { A-70 } \\
\text { A. K }\end{array}$ & 22 & 女 & 口 蓋 & 3 & \begin{tabular}{|l} 
手 術 2 \\
放射線 3
\end{tabular} & DC & 1 力月 & 1 年 5 力月 & 定型像＜非定型像 & 定型像＜非定型像 \\
\hline & $\begin{array}{l}\text { A-3 } \\
\text { I.T }\end{array}$ & 46 & 男 & 口 蓋 & 3 & 手 術 4 & A & 10 年 & 10 年 9 カ月 & 不明 & 定型像＜非定型像 \\
\hline
\end{tabular}

表 9 二次症例の再発

\begin{tabular}{|c|c|c|c|c|c|c|c|c|c|c|}
\hline & 例 & 年歯令 & 性 & 発現部位 & 再発回数 & $\begin{array}{l}\text { 治療方法 } \\
\text { 及び回数 }\end{array}$ & 予 後 & $\begin{array}{l}\text { 最初の治療 } \\
\text { 尞最初の } \\
\text { 再発さでの } \\
\text { 期 }\end{array}$ & 全 経 過 & 像 \\
\hline 1 & A-4. K.H & 41 & 女 & 口 蓋 & 1 & 手術 2 回 & $\mathrm{DC}$ & 13年 & 18年10力月 & 定型像>非定型像 \\
\hline 2 & A-11. F.M & 48 & 男 & 口 底 & 1 & $\begin{array}{l}\text { 手 術 } 1 \\
\text { 放射線 } 1\end{array}$ & $\mathrm{DC}$ & 4 力月 & 4 年 6 力月 & 定型像＜非定型像 \\
\hline 3 & A-14.K.K & 38 & 女 & 煩 部 & 9 & $\begin{array}{c}\text { 手 術 } 9 \\
\text { 放射線 } 1\end{array}$ & $\mathrm{AC}$ & 2 年 & 15年 & 定型像>非定型像 \\
\hline 4 & A-15. U.S & 47 & 女 & 上顎洞 & 4 & $\begin{array}{l}\text { 手 術 } 2 \\
\text { 放射線 } 1\end{array}$ & $\mathrm{DC}$ & 6 年 4 力月 & 15年 & 定型像＜非定型像 \\
\hline 5 & A-20.S.S & 36 & 女 & 口 底 & 2 & $\begin{array}{l}\text { 手 術 } 2 \\
\text { 放射線 } 2\end{array}$ & DC & 9 力月 & 11 年 4 力月 & 定型像>非定型像 \\
\hline 6 & A-44. I.K & 57 & 男 & 上口唇 & 6 & $\begin{array}{l}\text { 手 術 } 2 \\
\text { 放射線 } 5\end{array}$ & $\mathrm{DC}$ & 5 力月 & 11年11カ月 & 定型像＜非定型像 \\
\hline
\end{tabular}


が，充実性または管状腺癌椂構造の非定型像が多 い。核は大小不同で異型性が多少みられた。転移 巣では充実性増殖像で胞栄中心部に壊死を伴う非 定型像が多い。核も大きく異型性が認められた。

\section{4. 再発について}

再発が組織学的に確恐された症例は一次症例 で 10 例（表 8 ), 二次症例で 6 例（表 9 ）であっ た。

\section{a . 一次症例の再発}

発現部位別では表10の如くであり, 症例数が少 ないので確定的な事は言えないが，舌，煩に生じ た症例で再発が比較的多い。

表10 発現部位別症例数 (一次症例再発例)

\begin{tabular}{|c|c|c|c|c|}
\hline \multicolumn{2}{|c|}{ 舌 } & 2 例 & $2 / 5$ & $40 \%$ \\
\hline 口 & 蓋 & 5 例 & $5 / 23$ & $21.7 \%$ \\
\hline 口 & 唇 & 1 例 & $1 / 5$ & $20 \%$ \\
\hline \multicolumn{2}{|c|}{ 煩 } & 1 例 & $1 / 3$ & $33.3 \%$ \\
\hline 口 & 底 & 1 例 & $1 / 16$ & $6.3 \%$ \\
\hline
\end{tabular}

海発例の初回の治療状態は表11に示す如くであ り, 一次症例の再発例は部分切除例で多い。また 初回治療から再発までの期間は 2 力月から 10 年で 平均 2 年 9 カ月であった。また再発回数は 1 回か ら 3 回で平均 1.7 回であった。

\section{表11 再発例の初回治療状態（一次症例再発例）}

外科処置

腫瘍部分切除

広汎な切除

$$
5 \text { 例 }
$$$$
2 \text { 例 }
$$

$\begin{array}{cc}\text { 放射線治療 } & 3 \text { 例 } \\ \text { 合 計 } & 10 \text { 例 }\end{array}$

これらの症例の発現部位における組織像は定型 像が主体をなす例が 3 例, 他の 6 例では非定型像 が定型像に比して多かった。非定型像では管状腺 癌様の像が最も多く10例中 6 例に認められ，次い で充実性増殖像が 4 例に認められた。再発部位に おける組織像は 1 例以外は非定型像が定型像に比 して多く，非定型像では充実性増殖像が最も多く 10例中 8 例に見られ，次いで管状腺癌様像と小胞 巣の索状浸潤性増殖像が 4 例に認められた。
表12 発現部位別症例数（二次症例再発例）

$\begin{array}{lrrrrr}\text { 口 } & & \text { 底 } & 2 \text { 例 } & 2 / 16 & 12.5 \% \\ & \text { 煩 } & & 1 \text { 例 } & 1 / 3 & 33.3 \% \\ \text { 上 } & \text { 顎 } & \text { 洞 } & 1 \text { 例 } & 1 / 2 & 50.0 \% \\ \text { 口 } & & \text { 唇 } & 1 \text { 例 } & 1 / 5 & 20.0 \% \\ \text { 口 } & & \text { 蓋 } & 1 \text { 例 } & 1 / 23 & 4.3 \% \\ \text { 合 } & \text { 計 } & 6 \text { 例 } & & \end{array}$

b. 二次症例の再発例

部位別には表 12 の如く，上顎洞に発症した例に 多い。初回治療後再発までの期間は 5 力月から 13 年にわたり，平均 3 年10力月であった。再発回数

（来院時の再発を含屯）は腫瘍死例では 1 回から 6 回で平均 2.8 回, 腫瘍を有し生存している 1 例 は15年間に 9 回の再発を繰り返し，そのつど手術 ならびに放射線治療を受けていた。

来院後 (再発) の組織検査による腫瘍の組織像 は，囊胞状腔形成のみられる胞策が散在性あるい は密に増殖した定型像を示すものが 6 例中 3 例に 見られた。非定型像では間質が硝子化し，実質は 小胞巣の索状浸潤性増殖像が多く6 例中 4 例, 管 状腺癌様像と充実性増殖像が 6 例中 3 例に認めら れた口

\section{5. 追跡調查}

予後は69例中62例が追跡調査の結果明らかにな った。生存例は62例中 32 例 $(51.6 \%)$ で, 死亡確 認例は 30 例 $(48.4 \%)$ であった（表13）。

表13 予後追跡調査

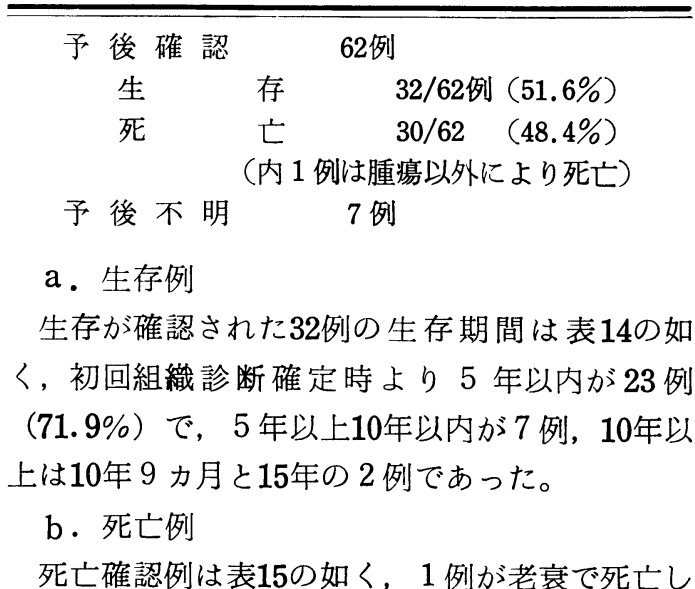


表14 生存確認例

\begin{tabular}{cccc}
\hline \hline 5 年以内 & & $23 / 32$ 例 & $(71.9 \%)$ \\
5 年以上 & 10 年以内 & $7 / 32$ & $(21.9 \%)$ \\
10 年以上 & & $2 / 32$ & $(6.3 \%)$ \\
表15 & 腫瘍による死亡確認例 & $(29$ 例) \\
\hline \hline 5 年以内 & & $21 / 29$ 例 & $(72.4 \%)$ \\
5 年以上 & 10 年以内 & $4 / 29$ & $(13.8 \%)$ \\
10 年以上 & & $4 / 29$ & $(13.8 \%)$
\end{tabular}

た以外すべて腫瘍による死亡であった。初回組織 診断確定後 5 年以内の死亡は21例 $(72.4 \%), 5$ 年 以上 10 年以内が 4 例 $(13.8 \%), 10$ 年以上経過後の 死亡確認例は 4 例で, 11 年 4 力月, 12 年, 15 年と 18年10カ月であった。

\section{c．頸部リンパ節転移例の予後}

頸部リンパ節転移例 6 例中 4 例は生存, うち 2 例(術後 1 年 2 力月と 5 年)は腫瘍を認めないが, 他の 2 例（術後 1 年 8 力月と 3 年 2 力月）は肺に 転移が認められている。また 2 例（1 年 6 力月と 5 年）は腫瘍死であった。頸部廓清で転移を認め 得なかった 3 例(術後 1 年 9 力月, 3 年, 3 年)は, いずれも生存し腫瘍は認められていない。

\section{d. 再発例と予後}

一次症例の再発例の予後は10例中 7 例が腫瘍死 で, 1 例は腫瘍確認さるも生存, 1 例が腫瘍確認 されず生存, 他の 1 例は不明で腫瘍死が圧倒的に 多い。腫瘍死で診断確定から死亡までの期間は 1 年 5 力月から 9 年に及び平均 4 年 5 力月である。

二次症例の再発例の予後は腫瘍死が 5 例, 腫瘍 を有するのが生存しているものが 1 例であった。 腫瘍死例の診断確定から死亡までの期間は 4 年 6 力月から 18 年 10 力月に及び平均 12 年 3 力月で, 腫 瘍を有し生存している 1 例は15年であった。18年 10力月で死亡した腫瘍死例は定型像の方が非定型 像に比して多かった。また15年後に腫瘍死した例 では非定型像の方が定型像に比して多かったが, 実質は基底細胞腺腫様像であった。腫瘍を有し, 15年生存している例では定型像が主体をなしてい た。

e. 組織像と予後
1） 5 年以内の生存例（腫瘍確認されない生存 例, 䰤瘍確認された生存例）と腫瘍死例の組織像 の比較 : 腫瘍死例では定型像より非定型像の部分 がかなり多く, 小胞栄の索状浸潤像, 管状腺癌様 像, 充実性増殖像が多い。生存例では定型像を示 す症例の方が多かったが管状腺癌様像あるいは充 実性増殖像などの非定型像も見られた。

2） 5 年以上の生存例（腫瘍確認されない生存 例, 腫瘍確認された生存例）之腫瘍死例の比較 : 生存例, 腫瘍死例共定型像, 非定型像にあまり量 的差異は認められない。

3） 5 年以上生存例（腫瘍確認されない生存 例, 腫瘍確認された生存例）と 5 年以内の腫瘍死 例との比較 : 5 年以内の腫瘍死例では 5 年以上の 生存例に比して非定型像を示すものが圧倒的に多 い。

\section{$\mathrm{f}$. 発現部位と予後}

5 年以上の生存例では煩部, 口蓋と舌に生じた 症例でやや多いが, 症例数が少ないので確定的な ことは言い得ない。5 年以内に死亡が確認された 症例では顎下腺と口唇に生じた例が多かった。

\section{IV. 考 察}

名称と独立性について：

本腫瘍は1859年 Billroth ${ }^{8)}$ が円柱腫 (cylindroma, Zylindrom) として記載したのが始めといわ れている。その後 Krompecher (1908) ${ }^{40)}$ は本腫瘍 をBasalzellenkarzinomとして分類し, Dockerty and Mayo (1942，1943) ${ }^{14,15)}$ は腺癌の 1 型とし 円柱腫型腺癌 (adenocarcinoma of the cylindroma type）なる名称で記載した。その他, 本腫 瘍には adenomyoepithelioma (Bauer and Fox 1945) ${ }^{6}$, basalioma (Ahlbom 1935, Ringertz 1938), adamantinoma (Naumann 1958), Pseudadenomatous basal-cell carcinoma (Smout and French 1961) ${ }^{52)}$ などの名称がある ${ }^{31,36,42) 。 ~}$ 一方, Ewing (1940) は本腫瘍に adenoid cystic carcinoma なる名を用い, 1954 年 Foote and Frazell がこの名称を一般化した ${ }^{31,42) 。}$

また，本腫瘍を近年まで独立した型とせず，多 
形性腺腫の中に分類する人もあった（Willis 1967 $\left.{ }^{62)}\right)$ 。しかし, 現在では本腫瘍は一般に adenoid cystic carcinoma（腺様囊胞癌）（Foote and Frazell 1954 ${ }^{25)}$, Moran $51^{1961^{44)}}$, Eneroth 1964 ${ }^{17)}$, Thackray 197259), Thackray and Lucas 197460)， あるいは adenocystic carcinoma (Evans and Cruickshank 197022) の名称で 1 つの独立した型の湩液腺腫瘍として分類されてい る。

発生頻度について :

本腫瘍の発現度は欧米では全潕液腺腫瘍の $6 \%$ 内外といわれている22)。大無液腺腫瘍のみでは 2 〜 4\%である ${ }^{36)}$ 。耳下腺では全腫瘍の 2 〜 \% 相当し22), Middlesex Hospital では耳下腺腫瘍 651例中3.3\%であり, Karolinska Sjukhuset で は 2,158 例の耳下腺腫瘍中 $2.3 \%$ にろ机たと いう60)。顎下腺では Simons ら $(1964)^{50)}$ は顎下 腺腫瘍の $13 \%$ に抢よび, 本腫瘍は顎下腺のもっ ともありふれた悪性腫瘍であるという。また Dockerty and Mayo ${ }^{14)}$ によ扟ば81例の顎下腺腫 瘍中15例 $(18.5 \%)$, Middlesex Hospital では60 例の顎下腺腫瘍中 $17 \%$ ，Karolinska Sjukhuset では170例の顎下腺腫瘍の15\%であったという60)。 舌下腺原発の腫瘍は稀で, Rankow and $\mathrm{Mi}^{-}$ gnogna (1969) ${ }^{48)}$ によると文献的に31例の舌下腺
腫瘍が記載されているが，その内22例が悪性であ るという。彼らは自験例15例の舌下腺原発腫瘍を 検索し，乙れらはすべて悪性腫瘍で，内 6 例が腺 様囊胞癌であったと述べている。わが国における 実態はあまり明らかでないが，太田(1955) ${ }^{45)}$ は大 液腺腫瘍 87 例中 9 例 (耳下腺 3 , 顎下腺 3 , 舌 下腺 3 ）に, 馬場ら $(1973)^{3)}$ は69例中10例（耳下 腺 2 , 顎下腺 6 , 舌下腺 2 ) に本腫瘍をみている。 小喠液腺における本腫瘍の頻度は高く, 表16の如 く $8 \%$ から $48 \%$ に抢よんでいる。小唾液腺での多 発部位は口蓋で, 表16の如く小匡液腺の腺様囊胞 癌中 $16.7 \%$ から $77.8 \%$ に達しており, Fine ら ${ }^{23)}$ ならびに Chaudhry ら ${ }^{11)}$ は自験例と文献例を検 討し，小唾液腺に生じた腺樣囊胞癌のうちそれぞ れ43\%と49\%が口蓋に生じていると述べている。 その他の部位では表17の如く舌，口底，煩あるい は上顎洞部に多い。

本研究における腺様囊胞癌69例は同期間中に当 教室で取り扱った全唾液腺腫瘍 386 例の $18 \%$ に相 当し ${ }^{35)}$ ，欧米に抢ける数值に比べてかなり高い が，てれは本教室で取り扱った涶液腺腫瘍に耳下 腺腫瘍が少ないことによるものである。顎下腺で は25例中 10 例で $40 \%$ ，小睡液腺では 323 例中 59 例 で18\%，口蓋腺では 196 例中 23 例で12\%を占めて いた。小㖶液腺での腺様囊胞癌の占める割合は既

表16 小唾液腺腫瘍中の腺様囊胞癌の割合と口蓋発生の頻度

\begin{tabular}{|c|c|c|c|c|c|c|}
\hline 報＼cjkstart告 & 報 告 年 & $\begin{array}{c}\text { 全腫 瘍 数 } \\
\mathrm{A}\end{array}$ & $\begin{array}{c}\text { 腺様囊胞癌数 } \\
\text { B }\end{array}$ & $\mathrm{B} / \mathrm{A} \%$ & $\begin{array}{c}\text { 口蓋症例数 } \\
\text { C }\end{array}$ & $\mathrm{C} / \mathrm{B} \%$ \\
\hline 太 $\quad$ 田 $^{45)}$ & 1955 & 88 & 9 & 10.2 & 2 & 22.2 \\
\hline Ranger $5^{47)}$ & 1956 & 80 & 30 & 37.5 & 5 & 16.7 \\
\hline 玉 生 ${ }^{57)}$ & 1959 & 62 & 5 & 8.0 & 3 & 60.0 \\
\hline Fine $5^{23)}$ & 1960 & 79 & 13 & 16.5 & 5 & 38.5 \\
\hline Chaudhry $5^{11)}$ & 1961 & 94 & 19 & 20.0 & 10 & 52.6 \\
\hline Bardwil ${ }^{4)}$ & 1967 & 100 & 48 & 48.0 & & \\
\hline Stuteville $ら^{55)}$ & 1967 & 80 & 36 & 45.0 & 28 & 77.8 \\
\hline 川 $5^{36)}$ & 1969 & 205 & 28 & 13.7 & 11 & 39.3 \\
\hline 林 $5^{28)}$ & 1972 & 160 & 23 & 14.4 & 6 & 26.1 \\
\hline 馬＼cjkstart場 $5^{3)}$ & 1973 & 42 & 9 & 21.4 & 2 & 22.2 \\
\hline Spiro $5^{53)}$ & 1973 & 492 & 174 & 35.4 & 65 & 37.4 \\
\hline
\end{tabular}


表17 小唾液腺での腺様囊胞癌発生部位の主な報告例

\begin{tabular}{|c|c|c|c|c|c|c|c|c|c|c|c|c|c|c|}
\hline & $\begin{array}{l}\text { 部 } \\
\text { 位 }\end{array}$ & $\begin{array}{l}\text { 口 } \\
\text { 蓋 }\end{array}$ & $\begin{array}{l}\text { 口 } \\
\text { 唇 }\end{array}$ & 煩 & 舌 & $\begin{array}{l}\text { 扁 } \\
\text { 桃 }\end{array}$ & $\begin{array}{l}\text { 口 } \\
\text { 底 }\end{array}$ & $\begin{array}{l}\text { 歯 } \\
\text { 槽 } \\
\text { 部 }\end{array}$ & $\begin{array}{l}\text { 咽 } \\
\text { 頭 }\end{array}$ & $\begin{array}{l}\text { 顎 } \\
\text { 骨 }\end{array}$ & $\begin{array}{l}\text { 上 } \\
\text { 顎 } \\
\text { 洞 }\end{array}$ & $\begin{array}{l}\text { 鼻 } \\
\text { 腔 }\end{array}$ & $\begin{array}{l}\text { 喉 } \\
\text { 頭 } \\
\end{array}$ & 他 \\
\hline Fine $5^{23)} \quad 1960$ & 111 & 48 & 7 & 10 & 21 & 1 & 19 & 3 & 2 & & & & & \\
\hline $\begin{aligned} & \text { Chaudhry } \text { '11) } \\
& 1961\end{aligned}$ & 234 & 114 & 14 & 20 & 63 & & & & & 14 & & & & 9 \\
\hline 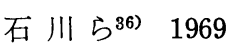 & 28 & 11 & & 2 & 2 & & 8 & & & & & & & 5 \\
\hline 藤林 ら ${ }^{28)} 1972$ & 23 & 6 & & 4 & 3 & & 7 & 1 & 2 & & & & & \\
\hline Spiro $\bigsqcup^{53)} 1973$ & 174 & 65 & 1 & & 27 & 2 & 5 & 11 & 5 & & 29 & 14 & 3 & \\
\hline
\end{tabular}

報告と大差なく，また絶対数が口蓋に多いてとも 同様であるが，顎下腺での割合が当教室において はかなり高い值を示していたてとは特徵的であ る。

\section{臨床的事項について：}

本腫瘍はいかなる年齢層にも生ずるが，従来の 報告では40歳から60歳までに多い31,49,60)。本研究 でも年㱓分布は 40 歳から70歳までが全体の約 $70 \%$ を占め，今までの報告と同様であった。性差につ いては，欧米では差はないが，女性にいくぶん多 いといわれている60)。また，大眰液腺例ではいく ぶん女性に多いが，顎下腺と口蓋では性差はない ともいう18,19)。本邦では石川ら ${ }^{36)}$ は 32 例中女が 男の約 2 倍を占めていたという。馬場ら 3) は大小 唾液腺の腺様囊胞癌19例で性差はほほ $1 ： 1$ であ り，秋本ら ${ }^{1)}$ も小崜液腺に生じた例で男 15 ：女 14 とほぼ同数を示している。本研究では女48例, 男21例で女性が男性の 2 倍強であり, 他の報告と は異なり女性に多いことが注目される。

病理組織学的所見について

組織学的にはすでに記載されている如くかなり 多様な像を示し, McDonald and Havens(1948) ${ }^{4}{ }^{3}$ は本腫瘍を Swiss cheese pattern と tubular pattern $に$, Thackray and Lucas ${ }^{58)}$ は cystic pattern と solid pattern に, Moran ら $(1961)^{44)}$ \& glandular, solid cords, relatively solid areas に, 秋本ら は節状型, 充実型, 索状型に 分けている。本研究では実質が本腫瘍の典型像と されているいわゆる節状構造を示す定型像と，そ れ以外に他の重液腺腫瘍と鑑別を要する非定型像
に2大別した。

定型像 : Thackray and Lucas ${ }^{58)}$ の cystic pattern に相当し, 腫瘍実質は胞巣状に増殖し, 各胞前内に小腺管状腔と囊胞状腔の 2 種類の腔を みる。

囊胞状腔の大きさは種々で, 腔壁は扁平な腫瘍 細胞でふちどられている。腔内内容物はへマトキ シリンに一様に淡染する希薄な粘液様物からエオ ジンに均一に染色される硝子様物まで種々であ る。粘液様物はムチカルミン, アルシアンブルー 染色陽性, PAS反応弱陽性で, 高度の マジーを示し, ヒアルロニダーゼ消化後メタクロ マジーは著しく減少するという2。本研究での粘 液様物質に対する染色結果は，乙れらの報告所見 とほほ同様であった。鍍銀染色では腔内に銀粒子 が沈着, 微細な好銀線維がみられることもある が，実質細胞に接する部位には，鹿野37〕述べて いる如く明確な膜状形態の基底膜は認められなか った。また, 囊胞状腔内硝子様物は偏光顕微鏡の 観察ではムコ多糖類の層状々セルと推定される (Friborsky) ${ }^{26)}$ 。Tandler (1971) ${ }^{56)}$ は電顕的には 囊胞状腔の硝子様物は肥厚した基底膜と fineな filament の集合物であろうと述べている。いず れにしてもこの囊胞状腔は真の管腔ではないとい うことは多くの研究者の一致した見解である。

小腺管状腔は少ないが腫瘍細胞成分に富んだ部 位にみられ，乙の組織構造は本腫瘍が腺癌の一種 と考えられている根拠となっている。小腺管状 腔形成細胞は腔を囲む $1 \sim 2$ 層の立方状細胞で胞 体は好酸性である。Thackray and Lucas ${ }^{58)}$ は 
この細胞は正常睡液腺の導管類似の細胞で, lumenal cell と呼び，多分分泌能を有すると述 べている。電顕的にも乙の腺管状腔形成細胞には 微小繊毛がみられ，隣接細胞間には junctional complex が認められている56)。時に腺管状腔内 にはエオシンン染まる粘液様物がみられ，組織化 学的に, 乙の腔内容物は PAS 反応強陽性でム千 カルミン, アルシアンブルー染色は陰性でメタク ロマジーは示さない2)。本研究に抢ける所見もほ ぼ同様であった。

腫瘍細胞は類円形の濃染する小型の核を有する 多角形の細胞で，胞体は比較的乏しく，配列は一 般に疎である。Thackray and Lucas ${ }^{58)}$ はこれ らの腫瘍細胞は正常の導管の筋上皮細胞に類似し ているという。電顕的には比較的長くのびた突起 で接した多角形の細胞でデスモゾームはなく，細 胞間は一般に開いており，かなり多採な像を示 す56)。Hoshino and Yamamoto ${ }^{33)}$ は電顕的に 2 種類の腫瘍細胞を区別し, 一方は筋上皮性細胞, 他は分泌型細胞であり，両型の移行もあったと言 う。また, 電顕的に腫瘍内に筋上皮細胞に似た細 胞の出現をみたが筋上皮細胞と確認するにいたら なかったとの報告もある ${ }^{29,56)}$ 。最近, Chisholm ら $(1975)^{12)}$ は小涶液腺の本腫瘍について電顕的に 検索し, 量的には duct-type の細胞が大部分を占 めているが，筋上皮型細胞および腺房型細胞も少 量あり, また, 腫瘍細胞の多くで細胞質にtonofilament の束が不規則に分布して扁平上皮化生と みなされる所見のあることも，本腫瘍に特徴的で あると述べている。いずれにしても光顕的に筋上 皮性細胞の存在を確証しうる方法を見出すことは 今後の問題の 1 つであろう。腫瘍細胞は異型性な ど細胞学的に悪性を思わせる所見は認められてい ない。間質は疎なあるいは硝子化した線維性結合 組織で, 時には細胞成分が少なく粘液腫状を呈す るとともある。Thackray and Lucas ${ }^{58)}$ は間質 の硝子化は基質線維の変質あるいは腫瘍細胞の産 生によるものであるという。

非定型像 : 腺樣囊胞癌の変異像と解される種々 の像が観察されるが, これらの変異像は腫瘍細胞
の分化の程度の差として解されよう。すなわち， 本腫瘍は腺管状構造形成の程度により, 多形性腺 腫様, 基底細胞腺腫様, 囊腫状あるいは管状ない し充実性腺癌様像を示すものと考える。腺管状構 造と囊胞状構造の区別には, 所見に記した如く腔 内容物の PAS 反応, ムチカル之ン,アルシアンブ ルー染色などの染色性の差異がよい指標となり得 た。充実性増殖像についてはすでに何人かの記載

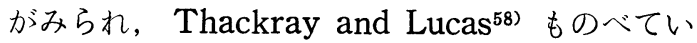
る如く，充実性に増殖した胞巣内を詳細に観察す ると小さな腺管状あるいは囊胞状構造をみる。し かし, 腫瘍細胞は定型像にみられたものに比し, 核, 胞体がやや大きく, 配列は密で, 時に大きな胞 巣の中心部に壊死がみられる。著者もこの種の充 実性増殖像を有する例は, 腺様囊胞癌として分化 のもっとも悪い像と理解している。その他の変異 像として Thackray and Lucas ${ }^{58)}$ は Neurinoma 類似の像と lumenal cell の acinar arrangment を挙げているが，本研究資料にはてれらの像を示 す例は認められなかった。

組織発生について:

本腫瘍の組織構成には, 多形性腺腫と同様筋上 皮細胞,ならびに腺管形成細胞あるいは分泌細胞 が主要な役割を演じていると考えられている (Thackray and Lucas ${ }^{58,60)}$ )。腺管形成細胞は腺 管状腔を形成し，管腔内に粘液様物を分泌する。 時には腺管状腔が発達し, 腺腫様あるいは管状腺 癌様構造を示すものと考えられる。霊胞状腔は今 までにも指摘されている如く，単一な方法で形成 されるものではないようである。1つは，実質内 の比較的疎な腫瘍細胞間に腫瘍細胞の分泌により 粘液が貯溜し，それが囊胞に発展する。他は実質 細胞塊が索状に増殖し, 粘液腫様の間質をとり囲 み囊胞状腔を形成する場合である。いずれにして も, 形成された囊胞状腔内に腫瘍細胞から分泌さ れた粘液様物が貯溜することにより囊胞状腔内は 硝子化する。ある場合には, 硝子化した囊胞状腔 が崩壊して硝子化した間質とつながり, 腫瘍実質 は小さな索状増殖像を呈するものと思われる。 Fukushima ${ }^{29)}$ は電顕的に腺様囊胞癌では実質細 
胞から間質に直接分泌する異常な上皮性ムチンを 立証している。そして, 間質の硝子化は異常な上 皮性分泌による間質組織の変性的変化の結果であ ると述べている。また, 本腫瘍において筋上皮細 胞がきわめて重要な役割を演しているであろうこ とは以前から指摘されている(Bauer and $\mathrm{Fox}^{6)}$, Thackray and Lucas $^{58)}$ )。

Hübner ら (1969) $)^{34)}$ Kleinsasser ら ${ }^{39)}$ が 多形性腺腫や腺様囊胞癌に抢ける上皮細胞あるい は筋上皮細胞の分化と機能の変異は, 腫場の異な った構造や発育様式に対する説明に重要なもので あろうと指摘している如く, 本腫瘍の組織発生の 解明には, これら細胞の生物学的な動態や意義づ けを, 今後さらに詳細に検索する必要があるもの と思われる。

本腫瘍の発生母地としては, 導管と終末部の雨 者を考える人 (Foote and Frazell) ${ }^{24)}$, 筋上皮細 胞の関与を主張する人 (Bauer and Fox) ${ }^{6}$ や, 介在部を発生母地として考えている人（Eneroth ら)20)がいる。Azzopardi and $\operatorname{Smith}(1959)^{2)}$ は 組織化学的検索結果より, 本腫韵之多形性腺腫は いずれも介在部から生ずるもので, 本腫瘍は比較 的末分化な型であると述べている。 Bruce and Wertheimer (1967) ${ }^{10)}$ は酵素組織化学的研究よ り本腫瘍は小棰液腺の導管細胞に由来すると述べ ている。最近の電顕的研究では, 介在部に発生母 地を求める報告が多い(Kleinsasser ら ${ }^{39}$, Hübner $\zeta^{34)}$, Hoshino and Yamamoto $\left.{ }^{33)}\right)$ 。

鑑別診断について :

本腫瘍の鑑別診断としてもっとも問題にされて いるのは重液腺の多形性腺腫（いわゆる混合腫 瘍）である7,9,17,22,44,48)。その他 spheroidal cell carcinoma $^{58)}$, mucoepidermoid carcinoma ${ }^{44)}$, squamous cell carcinoma ${ }^{44)}$, mucous producing adenopapillary carcinoma ${ }^{9)}$ trabecular or solid adenocarcinoma ${ }^{7,17)}$, anaplastic adenocarcinoma ${ }^{60)}$, adenocarcinoma with pseudoadamantinomal pattern ${ }^{60)}$, mucous cell adeno carcinoma ${ }^{60)}$ などである。多形性腺腫との鑑別 は多形性腺腫が一般に被包され, 周囲組織との境
界も明瞭なとと, 粘液腫様あるいは軟骨腫様像の 出現するてとなどに対して, 本腫瘍では被包はほ とんどなく, 周囲組織へ浸潤性に増殖し,特に神経 周囲への浸潤性増殖, 円柱腫状構造などのあるこ とにより区別しうるといわれている。Thackray and Lucas $^{58)}$, Blanck ${ }^{9)}$ が指摘している如く, 間質の粘液性変化が両者間でもっともまぎらわし い点である。しかし多形性腺腫では上皮細胞がム チンと混在しているのに対し, 腺様囊胞癌ではム チンは上皮細胞と明確に区別されている点がもっ とも鑑別に役立つという58)。また時に多形性腺腫 の對状の増殖像は腺様囊胞癌とまぎらわしいとい われている58。Foote and Frazel125) は多形性腺 腫のてのような部分を pseudo-adenoid cystic と 呼び多形性腺腫の約10\%にみられると述べてい る。Evans ら 21) は多形性腺腫内に円柱腫様像を 有する例を pseudo cylindroma として記載して いる。Blanck ら ${ }^{9)}$ は良性の混合腫瘍より悪性型 の方が腺様囊胞癌と鑑別がむずかしいといい，粘 液腫様あるいは軟骨腫様組織の出現のみが鑑別診 断として役立つであろうという。

本研究に打いても非定型像内に多形性腺腫類似 の像をみたが，ある程度の大きさの標本で，今ま での報告に示されているような点に注意して検索 するならば，鑑別診断はさほど困難でないと考え る。 Mucous producing adenopapillary carcinoma, poorly differentiated solid carcinoma やその他の腫瘍とも腺管様構造, 囊胞様構造ある いは円柱腫状構造に留意して検索するならば, 鑑 別は困難でないものと思う。唾液腺腫瘍は全般に 像は多彩であるので, 検索標本のある程度の大き さが要求されるのは当然のてとである。

拡がりについて:

本腫瘍は周囲組織に対し浸潤性に増殖する。し ばしば腫瘍が神経線維周囲あるいは神経線維束内 に浸潤性に発育するといわれ, 臨床的には知覚異 常, 局所の疼痛, 顔面神経麻瘏を生ずる。Conley and Dingman ${ }^{13)}$ によると知覚異常は耳下腺に生 じた例で $20 \%$ ，顎下腺では $13 \% ， 小$ 睡液腺では18 \%, 舌下腺では $33 \%$ にられたという。局所の疼 
痛は腺様囊胞癌の 25〜50\%に (Gläser) ${ }^{30)}$, 顔面 神経麻痺は25\%(Kirklin ら) ${ }^{38)}$ にみられたとい う。神経線維束内あるいは周囲への本腫瘍の増殖 について，Blanck ら ${ }^{9)}$ は耳下腺に生じた 35 例中 16例に喼め，また神経線維束内あるいは周囲に浸 潤のあった16例中13例が腫瘍で死亡しており，対 照のとの部に浸潤のみられなかった例では19例中 8 例が腫瘍死していたにすぎなかったという。秋 本ら 1 も大小睡液腺の29例を検索し10例に同様の 所見をみている。本研究に㧈いても25例 $(36.3 \%)$ の症例で神経線維束内あるいは周囲に腫瘍の浸潤 性増殖をみた。乙の出現頻度は勿論検索する標本 の大きさ，量に関係するが，本検索では腫瘍発現 部位ならびに組織像との間に明確な相関関係は見 出し得なかった。

本腫瘍ではまた隣接骨組織内へも浸潤性に増殖 する像がしばしば認められる。Fine ら23)は小棰 液腺例13例中 4 例で, Moran ら 4 ) は 38 例を検討 し, 口蓋, 咽頭, 涙腺例15例中13例に隣接骨組織 への腫瘍の浸潤をみたと述べている。本研究でも 10例に顎骨内浸潤が認められ，上頜洞，口蓋，顎 下腺，臼後部に生じた例であった。

転移は予後に対し重要な意義を有する。本腫瘍 は発育が緩慢で転移を認めるまでにかなり期間を 有し, 転移巣での腫瘍の発育もゆっくりしている 点は他の悪性腫瘍と多少異なる。堀内ら ${ }^{27)}$, 藤林 ら 28) は本腫瘍の肺転移巣の増大率を doubling time から推定し, doubling time は220日から 600 日あるいは108日から 818 日にも及び，seminoma の肺転移巣のそれが25日から50日，扁平上 皮癌の肺転移巣では 150 日前後に比してはるかに 大であるという。そして本腫瘍は原発巣と同時に 肺転移巣の増殖もまた緩慢なものであると述べて いる。しかし，転移について剖検例を基にした詳 細な報告例は少ない。

頸部リンパ節転移の頻度は従来の報告によ扎ば 約 20\%（15３0\%）の症例に認められ $9,13,16,18,19$, 23,32,44,51)，顎下腺に生じた例が他の部位に生じた 例に比較してやや高率である18)。本研究では頸部 廓清術を行い組織学的に検索した症例 9 例中 6 例
と剖検例 4 例に頸部リンパ節転移が認められ，乙 れは全検索例の $14 \% に$ 相当する。原発部位別には 頸部廓清術例で臼後部に生じた例に頸部りンパ節 転移が多かったが，症例数が少ないので確定的な ことはいい得ない。遠隔転移の頻度は約 $40 \%$ (17 ～68\%）の症例にみられている ${ }^{9,13,16,18,19,23,32,44) 。}$ 遠隔転移部位は肺が最も多く，全症例の約 $30 \%$ (20 55\%)の症例にみられている。その他骨に約 10\% (2.8 15.4\%), HTに約 $5 \%(2.7 \sim 15.4 \%)$, その他，腎，兴，胸膜などに転移が認められてい る。本研究では４例の剖検例があり，4 例とも血 行性あるいはリンパ行性に広汎な転移が浔められ た。特に肺，肝，骨への転移が著しかった。発症 後死亡までの全経過いずれも長く 5 年 8 カ月から 12 年までで平均 7 年 6 力月であった。その間何回 かの再発，治療をうけている。

局所再発について:

従来の報告によれば再発の頻度は，大小睡液腺

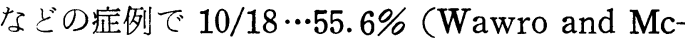
Adams) ${ }^{61)}, 9 / 54 \cdots 16.7 \%$ (Eby $\left.ら\right)^{16)}, 10 / 29 \cdots$ $34.5 \%$ (秋本ら) ${ }^{11}, 56 / 134 \cdots 42 \%(\text { Conley } 5)^{13)}$, 耳下腺のみの症例で $21 / 35 \cdots 60 \%$ (Blanckら) ${ }^{9}$, $5 / 21 \cdots 24 \%$ (Quattlebaum ら) ${ }^{46)}, 2 / 19 \cdots 11 \%$

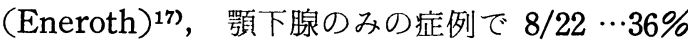
(Eneroth and Hjertman) ${ }^{18)}$, 小睡液腺症例で

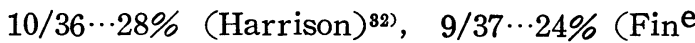
ら ${ }^{23)}$, 口蓋腺症例で $12 / 32 \cdots 38 \%($ Eneroth にみられている。以上の如く，再発の頻度は顎下 腺でやや多い傾向がみられるが，発現部位別の差 はあまり明確ではない。本研究では舌，煩ならび に上顎洞部に生じた例で再発が多かったが，症例 数が少ないので確定的なととはいえない。

初回治療後再発までの期間は一般に長いのが特 徵である(Moran ら ${ }^{44)}$ ，Smith ら ${ }^{51)}$ )。Smith らは局所再発の大部分は 8 年以内にみられ，その 内半数は 5 年以内に生じていると述べている。 Fine 万23) は再発は治療後 4 力月から 4 年までに 生じており, 文献的検索では16例の再発例で, 7 カ月から 5 年までの間に再発しているという。秋 本ら ${ }^{1)}$ の観察では治療後再発までの期間は 1 年か 


\begin{tabular}{|c|c|c|c|c|}
\hline & 5 年 & 10年 & 15年 & 20 年 \\
\hline \multicolumn{5}{|l|}{ 耳下腺 } \\
\hline Kirklin ら $1951^{38)}$ & $78.7 \%$ & $41.9 \%$ & $28.3 \%$ & $0 \%$ \\
\hline Blanck ら 19679) & 73.0 & 39.0 & 21.0 & 13.0 \\
\hline \multicolumn{5}{|l|}{ 顎 下腺 } \\
\hline Simons $51964^{50)}$ & 50.0 & 39.0 & 0 & 0 \\
\hline Eneroth $ら 1966^{18)}$ & 50.0 & 25.0 & 0 & 0 \\
\hline \multicolumn{5}{|l|}{ 口蓋腺 } \\
\hline Eneroth 5 1968 ${ }^{19)}$ & 80.0 & 44.0 & 38.0 & 36.0 \\
\hline \multicolumn{5}{|l|}{ 小唾液腺 } \\
\hline MacDonald ら 1948 & 59.0 & & & \\
\hline Fine $ら 1960^{23)}$ & 23.1 & & & \\
\hline \multicolumn{5}{|l|}{ 大小唾液腺 } \\
\hline Berdal ら $1970^{7)}$ & 27.5 & & & \\
\hline \multirow{2}{*}{$\begin{array}{l}\text { Leafstedt } 5 \text { 197141) } \\
\text { Conley } 51_{1974^{18}}\end{array}$} & 65.0 & 31.0 & 15.0 & \\
\hline & 74.0 & & & \\
\hline
\end{tabular}

ら10数年におよび平均 3.5 年であった。本研究で は治療後再発までの期間は一次症例で 2 力月から 10 年におよび平均 2 年 9 力月, 二次症例では 5 力 月から 13 年にわたり平均 3 年10カ月であった。

追跡調查について :

本腫瘍は一般に経過が長いので, 予後は少なく とも 5 年以上の長期の観察が必要であるといわれ ている。Foote and Frazell (1953) ${ }^{24)}$ は治療後 5 年以上経過し腫瘍を有しない患者はわずか $25 \%$ であると述べている。主な既報告者による生存率 は表18の如くであり, 腫瘍発生部位により数值は 多少異なる。大小哽液腺に生した例を比較した 際, Conley and Dingman (1974) ${ }^{13)}$ は 134 例 の大小唾液腺より生じた例を検討し，15年以上の 生存者はすべて大烸液腺症例で, 大唾液腺に生じ た腫瘍の方が予後は良好であると述べている。ま た大唾液腺では顎下腺に生じたものの方が耳下腺 のものより予後は悪い。乙れは顎下腺例で再発傾 向がやや多かったとととも関係するものと思われ る。

組織像と予後について:

Blanck ら (1967) ${ }^{9)}$ は 35 例の耳下腺の腺様囊 胞癌について, 組織像と予後との関係を詳細に検
討し, 細胞分裂像が少ない例では 27 例中 14 例 (51.9\%) が腫瘍で死亡しており，多い例では 8 例中 7 例 $(87.5 \%)$ が腫瘍で死亡していた。また 浸潤性増殖像が多くみられた例では 28 例中 18 例 $(64.3 \%)$ ，少ない例では 7 例中 3 例 $(42.9 \%)$ が 腫瘍により死亡し, 細胞多形性は軽度の例24例中 14例 $(58.3 \%)$, 中等度の例11例中 7 例 $(63.6 \%)$ が腫瘍死であったという。Quattlebaum ら $(1946)^{46)}$ は充実性の腫瘍は他の型よりも悪性のよ うにみえるといい, Stewart (1961) 54) も壊死を 伴った細胞塊の像はより悪性の変異で, 細胞の核 は泡状で，核小体も明瞭であるという。彼の検索 例 6 例中 2 例がての像を呈しており，てれらは 2 例とも 2 年以内に死亡していると述べている。 Eneroth ら (1968) ${ }^{19)}$ も本腫瘍には高分化型と低 分化型のものがあり, 前者は篩状構造が著明で予 後もよい。一方, 後者は充実性増殖部が著明で予 後も悪いという。そして 32 例の口蓋例中 7 例にみ られ， 7 例とも 3 年以内に死亡しているという。

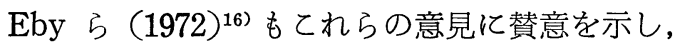
54例中 9 例で壊死を伴った充実性増殖像がみら れ，乙れらはいずれも診断後 3 年以内に死亡して 抢り，彼らはてれを fulminating progression であると述べている。本研究では 5 年以上の生存 例が 9 例, 5 年以内死亡確認例が 21 例であった。 組織学的に 5 年以内死亡例では 5 年以上の生存例 に比し非定型例が多く, とくに充実性増殖像, 索 状浸潤像, 管状腺癌様像が多かった。したがって 上記諸家の報告例と同様に，腺様囊胞癌ではてれ ら非定型像を示す例は予後は不良であると考えら れた。

\section{結論}

1. 1938年より1972年までの35年間に取り扱っ た腺様囊胞癌 69 例について検討した。

2. 年齢別では来院時 40 歳から70歳までが全体 の約70\%で，40歳代がもっとも多い。性別では女 性が男性の約 2 倍で, 従来の諸報告に比べ女性に 多いととが注目される。発現部位別には口蓋がも っとも多く全体の約 $1 / 3$ を占め, 口底および顎下腺 
がこれに次いだ。本腫瘍の倕液腺腫瘍に占める割 合は小唾液腺では $18 \%$ であったが，顎下腺では40 \%と従来の報告に比べ高かった。

3. 組織学的に, 実質がいわゆる笠状構造を示 す典型像が主体をなす定型例と，他の型の唾液腺 腫瘍との鑑別を要する種々の変異像が主体をなす 非定型例に 2 大別したが，前者は34例，後者は35 例であった。

4. 本腫痬は周囲組織へ浸潤性に増殖し, 腫瘍 を囲む被膜形成は組織学的に定型例, 非定型例の いずれにも認められなかった。腫瘍組織の神経線 維束周囲または内増殖像は症例の約 $36 \%$ に認めら れた。顎骨への浸潤は上顎洞部，口蓋，臼後部， 顎下腺に生じた例にみられ，また組織学的に非定 型例に多かった。

5. 再発が組織学的に確認された症例は一次症 例で10例 $(17 \%)$ ，二次症例で 6 例 $(67 \%)$ であっ た。

6. 転移は臨床的に頸部リンパ節転移が疑われ 摘出リンパ節を組織学的に検索した症例 9 例中 6 例で確認され，剖検例 4 例ではいずれも頸部りン パ節を含め広汎な遠隔転移が認められた。

7. 追跡調査では生存例か $52 \%$, 死亡確認例が $48 \%$ で，10年以上経過後の生存例は 2 例死亡例は 4 例であった。組織学的に非定型例で，とくに充 実性増殖像, 索状浸潤像, 管状腺澢様像を示す例 は予後が不良であった。

\section{謝 辞}

稿を終えるに際し，終始ご懇切なるご指導とご校 閲をいただきました石川梧朗教授，ならびに小守昭 助教授，種々のご支援をいただいた同教室の皆様に 衣心より感謝の意を表します。また標本作製の点で ご協力いただいた清野和夫氏，大貫頌子嬢に深く御 礼申し上げます。

なお，本研究における症例の臨床的事項に関する 記述は第 1 口腔外科学教室 (上野 正教授) および 第 2 口腔外科学教室 (伊藤秀夫教授) の記録による ものであり，また特に予後調査にご助力いただきま した第 1 , 第 2 口腔外科学教室各位に厚く御礼申し
上げます。

本研究の要旨は第14回蒾科基礎医学会総会（1972

年)で発表した。

\section{文献}

1) 秋本雅昭, 他: 腺様囊胞癌の臨床病理学的研 究, 神歯学, $7: 27,1972$.

2) Azzopardi, J. G. and Smith, O. D. : Salivary gland tumours and their mucins, J. Path. Bact. $77: 131,1959$.

3）馬場謙介, 他：唾液腺腫瘍一之の組織型と予後 一, 癌の臨床， $19: 893,1973$.

4) Bardwil, J.M. : Tumors of the parotid gland, Amer. J. Surg., 114 : 498, 1967.

5) Batsakis, J. G. : Tumors of the Head and Neck, Baltimore, 1974, The Williams and Wilkins Company.

6) Bauer, W. H. and Fox, R. A. : Adenomyoepithelioma (cylindroma) of palatal mucous glands, Arch. Path., 39 : 96, 1945.

7) Berdal, P., de Besche, A. and Mylius, E. : Cylindroma of salivary glands. A report of 80 cases, Acta Otolaryng., $263: 170,1970$.

8) Billroth, T. : Beobachtungen über Geschwülste der Speicheldrüsen, Virchow Arch., $17: 357,1859$

9) Blanck, C. et al. : Adenoid cystic carcinoma of the parotid gland, Acta Radiol., 6:177, 1967.

10) Bruce, B. A. and Wertheimer, F. W. : Enzyme histochemistry of adenoid cystic carcinoma of minor salivary glands, J. Oral Surg., $25: 30,1967$.

11) Chaudhry, A. P. et al. : Intraoral minor salivary gland tumors. An analysis of 1,414 cases, OS. OM. \& OP., $14: 1194,1961$.

12) Chisholm, D. M. et al. : A qualitative and quantitative electronmicroscopic study of the adenoid cystic carcinoma of human minor salivary glands, J. Oral Path., 4 : $103,1975$.

13) Conley, J. and Dingman, D. L. : Adenoid cystic carcinoma in the head and neck (cylindroma), Arch. Otolaryngol., $100: 81$, 1974.

14) Dockerty, M. B. and Mayo, C. M. : Primary tumours of submaxillary glands with special reference to mixed tumours, Surg. Gynec. Obst., 74: 1033, 1942.

15) Dockerty, M. B. and Mayo, C. W. : "Cylindroma"(adenocarcinoma, cylindroma type), Surgery, $13:$ 416, 1943. 
16) Eby, L., Johnson, D. S. and Baker, H. W. : Adenoid cystic carcinoma of the head and neck, Cancer, $29: 1160,1972$.

17) Eneroth, C. M. : Histological and clinical aspects of parotid tumours, Acta Otolaryng. Suppl., 191, 1964.

18) Eneroth, C. M. and Hjertman, L. : Adenoid cystic carcinoma of the submandibular gland, Laryngoscope, $76: 1639,1966$.

19) Eneroth, C. M. et al. : Adenoid cystic carcinoma of palate, Acta Otolaryng., $66: 248$, 1968.

20) Eneroth, C. M. et al. : Ultrastructural characteristics of adenoid cystic carcinoma of salivary glands, Arch. klin. exp. Ohr.-, Nas. -u. Kehlk. Heilk., 192 : 358, 1968.

21) Evans. J. C., Efskin, J. and Roberts, T. W. : Cylindroma. Amer. J. Roentgen., $96: 191$, 1966.

22) Evans, R. W. and Cruickshank, A. H. : Epithelial Tumours of the Salivary Glands, Philadelphia, London, Toronto, 1970, W. B. Saunders Company.

23) Fine, G., Marshall, R. B. and Horn, R. C. : Tumors of minor salivary glands, Cancer, $13: 653,1960$.

24) Foote, F. W., Jr. and Frazell, E. L. : Tumors of the major salivary glands, Cancer, 6 : 1065, 1953.

25) Foote, F. W. and Frazell, E. L. : Tumors of the Major Salivary Glands, Washington, D. C., 1954, A. F. I. P.

26) Friborsky, V.: Submicroscopical structure of adenoid cystic carcinoma of salivary glands, Acta Morph. Acad. Sci, Hung., 14 : 105, 1966.

27) 堀内淳一,他：口腔領域の腺様囊胞癌(Adenoid cystic carcinoma), その放射線治療経験, 臨 床放射線, $13: 457,1968$.

28）藤林孝司, 他：小唾液腺腫瘍の臨床的研究, 口 科誌, $21: 901,1972$.

29) Fukushima, M.: An electron microscopic study of human salivary gland tumors, Bull. Tokyo Med. Dent. Uuiv., 15 : 387, 1968.

30) Gläser, A. : Die Geschwülste der Kopfspeicheldrüsen, Berlin, 1962, V. E. B. Verlag Volk und Gesundheit.

31) Gorlin, R. J. and Goldman, H. M. : Thoma's Oral Pathology, St. Louis, 1970, The C. V. Mosby Company.

32) Harrison, K. : A study of ectopic mixed salivary tumours, Ann. Roy. Coll. Surg.
Eng., $18: 99,1956$.

33) Hoshino, M. and Yamamoto, I. : Ultrastructure of adenoid cystic carcinoma, Cancer, $25: 186,1970$.

34) Hübner, G., Kleinsasser, O. und Klein, H. J. : Zur Feinstruktur und Genese der Cylindrome der Speicheldrüsen, Virchow. Arch. Abt. A Path. Anat., $347: 296,1969$.

35) 石川梧朗 : 私信.

36) 石川梧朗, 秋吉正豊 : 口脫病理学II, 京都, 1969, 永末書店.

37）鹿野紳八郎：唾液腺腫瘍における基底膜の病理 組織学的研究, 口病誌, $31: 252,1964$.

38) Kirklin, J. W. et al. : Parotid tumors. Histopathology, clinical behaviour and end results, Surg. Gynec. Obst., 92 : 721, 1951.

39) Kleinsasser, O., Hübner, G. und Klein, H. J. : Zur Histogenese der Cylindrome, Arch. klin. exp. Ohr. -, Nas. -u. Kehlk. Heilk., 195 : 192, 1969.

40) Krompecher, E. : Zur Histogenese und Morphologie der Mischgeschwülste der Haut sowie der Speichel-und Schleimdrüsen, Beitr. Path. Anat., 44 : 51, 1908.

41) Leafstedt, S. W. et al. : Adenoid cystic carcinoma of major and minor salivary glands, Amer. J. Surg., 122 : 756, 1971.

42) Lucas, R. B. : Pathology of Tumours of the Oral Tissues, London, 1964, J. \& A. Churchill.

43) McDonald, J. R. and Havens, F. Z. : Study of malignant tumors of glandular nature found in nose, throat and mouth, Surg. Clin. North Amer., $28: 1087,1948$.

44) Moran, J. J. et al. : Adenoid cystic carcinoma; clinicopathological study, Cancer, $14: 1235,1961$.

45）太田邦夫：唾液腺腫瘍について（形態学的の問 題を中心に), 臨床病理, $3: 203,1955$.

46) Quattlebaum, F. W. et al. : Adenocarcinoma, cylindroma type of the parotid gland; a clinical and pathologic study of twenty-one cases, Surg. Gynec. Obstet., 82 : 342, 1946.

47) Ranger, D., Thackray, A. C. and Lucas. R. B. : Mucous gland tumours, Brit. J. Cancer, $10: 1,1956$.

48) Rankow, R. M. and Mignogna, F. : Cancer of the sublingual salivary gland, Amer. J. Surg., $118: 790,1969$.

49) Shafer, W. G., Hine, M. K. and Levy, B. M. : A Textbook of Oral Pathology, 3rd ed., Philadelphia, London, Toronto, 1974, W. B. Saunders Company. 
50) Simons, J. N., Beahrs, O. H. and Woolner, L. B. : Tumors of submaxillary gland, Amer. J. Surg., 108 : 485, 1964.

51) Smith, L. C. et al. : Cylindroma (adenoid cystic carcinoma); a report of 58 cases, Amer. J. Surg., 110 : 519, 1965.

52) Smout, M. S. and French, A. J. : Prognosis of pseudoadenomatous basal-cell carcinoma, Arch. Path., 72 : 107, 1961.

53) Spiro, R. H. et al. : Tumors of minor salivary origin. A clinicopathologic study of 492 cases, Cancer, $31: 117,1973$.

54) Stewart, J. : Carcinoma of salivary glands showing the cylindroma pattern, Brit. J. Surg., $49: 241,1961$.

55) Stuteville, O. H. and Corley, R. D. : Surgical management of tumors of intraoral minor salivary glands. Report of eighty cases, Cancer, $20: 1578,1967$.

56) Tandler, B. : Ultrastructure of adenoid cystic carcinoma of salivary gland origin, Labor. Invest., $24: 504,1971$.

57）玉生みい：唾液腺腫瘍の臨床的研究, 日口外誌, $5: 2,1959$.

58) Thackray, A. C. and Lucas, R. B. : The histology of cylindroma of mucous gland origin, Brit. J. Cancer, $14: 612,1960$.

59) Thackray, A. C. : International Histological Classification of Tumours. Histological Typing Salivary Gland Tumours, Geneva : World Health Organisation, 1972.

60) Thackray, A. C. and Lucas, R. B. : Tumors of the Major Salivary Gland, Washington, D. C., 1974, A. F. I. P.

61) Wawro, N. W. and McAdams, G. : Cylindromata of major and minor salivary glands, Arch. Surg., 68 : 252, 1954.

62) Willis, R. A. : Pathology Tumours. ed. 4, London, 1967, Butterworth and Co. Ltd. 